\title{
IRRESISTIBLE IMPULSE AS A DEFENSE IN THE CRIMTNAL LAW
}

\author{
By EDwin R. KeEDy $\dagger$
}

One of the most controversial questions in the field of Criminal Law is whether an irresistible impulse, produced by mental disease, should be a defense to a charge of crime. Statutes, court decisions and the opinions of writers are in direct conflict. The authors of two rather recent publications in England discuss the problem. Edward Robinson in a volume entitled Just Murder presents legal and medical arguments in favor of an affirmative answer to the question. ${ }^{1}$ The contrary position is taken by G. Ellenbogen in an article in the Journal of Criminal Science, published at Cambridge University. ${ }^{2}$ In the investigation conducted during the years 1949 and 1950 by the Royal Commission on Capital Punishment testimony was received from members of the medical and legal professions on the question whether irresistible impulse should be allowed as a defense. ${ }^{3}$ The purpose of this article is to present a statement of the law on the subject and to evaluate the reasons that have been advanced for and against allowing the defense.

In 1838 Dr. Isaac Ray, a distinguished physician, published in Boston a treatise on the Medical Jurisprudence of Insanity. In discussing the criminal responsibility of the insane he stated the follow-

$\dagger$ A. B., 1899, Franklin and Marshall College; LI. B., 1906, Harvard University; LL. D., 1926, Franklin and Marshall College, 1950, Ưniversity of Pennsylvania; Professor of Law Emeritus, University of Pennsylvania; Dean, University of Pennsylvania Law School 1940-1945; author of The Decline of Traditionalism and Indizidualism, 65 U. of PA. L. Rev. 764 (1917) ; The Third Degree and Legal Interrogation of Suspects, 85 U. OF PA. L. REv. 761 (1937); A Petition of Right: Archer-Shee v. The King, 87 U. of PA. L. REv. 895 (1939); The Preliminary Investigation of Crime in France, 88 U. oF PA. L. REv. 385, 692, 915 (1940); History of the Pennsylvania Statute Creating Degrees of Murder, 97 U. of PA. L. REv. 759 (1949); George Sharswood-Professor of Law, 98 U. oF PA. L. REv. 685 (1950); $A$ Problem of First Degree Murder: Fisher v. United States, 99 U. oF PA. L. REv. 267 (1950); A Remarkable Murder Trial: Rex v. Simisiak, 100 U. of PA. L. REv. 48 (1951); and articles in other legal periodicals.

1. Robinson, JUST MURder (1947).

2. Ellenbogen, The Principles of the Criminal Law Relating to Insanity, $1 \mathrm{~J}$. CrIM. Sct. 178 (1948).

3. The scope of the Commission's investigation is not limited to the problem of capital punishment, but includes a study of the tests for determining criminal responsibility when mental disease is set up as a defense to a criminal prosecution. When the Commission conducted hearings in this country in 1951, much stress was laid on this question. The report of the Commission has not yet been published. 
ing: "Now we have an immense mass of cases related by men of unquestionable competence and veracity, where people are irresistibly impelled to the commission of criminal acts while fully conscious of their nature and consequences; and the force of these facts must be overcome by something more than angry declamation against visionary theories and ill-judged humanity." 4

In February, 1843 Dr. Forbes Winslow published in London a volume entitled The Plea of Insanity in Criminal Cases, in which he stated the following:

"A person may be perfectly competent to draw a correct distinction between right and wrong, and yet labour under a form of insanity which ought unquestionably to protect him from legal or moral responsibility. I allude to cases of insanity where the patient is driven, by an irresistible impulse, to destroy, after struggling, for some time, against the morbid desire, being, at the same time, perfectly conscious that he is impelled to do what is wrong both in the sight of God and man." 5

The instructions to the jury in four trials, two in England and two in this country, which occurred between the years 1840 and 1846, are of particular significance in the development of the present problem. In 1840 Oxford was tried for treason for firing a pistol at Queen Victoria. The defense was insanity. In his charge to the jury Lord Denman, C. J. stated the following:

"The very important question comes, whether the prisoner" was of unsound mind at the time when the act was done? . . If some controlling disease was, in truth, the acting power within him which he could not resist, then he will not be responsible."

The defendant was acquitted.

4. Ray, The Medical Jurisprudence of Insanity 263 (1838).

5. Winslow, The Plea of Insanity in Criminal Cases 74 (1843).

"Sometimes his [the monomaniac's] conscience makes him turn with horror from the act which he is about to commit; but his will is overcome by the violence of his impulse." 2 MARC, DE LA FOLIE 25 (1840).

"In this disorder [instinctive madness] the will is occasionally under the influence of an impulse, which suddenly drives the person affected to the perpetration of acts of the most revolting kind, to the commission of which he has no motive. The impulse is accompanied by consciousness; but it is in some instances irresistible....." Prichard, ON the Different Forms of Insanity in Relation to Jurisprudence 87 (1842).

6. Reg. v. Oxford, 9 C. \& P. 525, 546 (1840). The context in which the quoted statement appears is as follows: "Then the very important question comes, whether the prisoner was of unsound mind at the time the act was done? Persons prima facie must be taken to be of sound mind till the contrary is shewn. But a person may commit a criminal act, and yet not be responsible. If some controlling disease was, in truth, the acting power within him which he could not resist, then he will not be responsible."

Professor Glueck in his discussion of Reg. v. Oxford states the following: "In this case the jury found the prisoner not guilty, being evidently more impressed with 
In 1843 M'Naughton was brought to trial for the murder of Edward Drummond, the private secretary of the Prime Minister, Sir Robert Peel. ${ }^{7}$ The evidence showed that the defendant was suffering from an insane delusion that he was being persecuted by the Prime Minister and other members of his political party. At the conclusion of the evidence the Solicitor-General, who conducted the prosecution, stated that the object was to ascertain "whether at the time the prisoner committed the crime he was at that time to be regarded as a responsible agent, or whether all control of himself was taken away?" 8 Tindal, C. J. who with Williams and Coleridge, JJ. presided at the trial, submitted to the jury the question "whether on the whole of the evidence you have heard, you are satisfied that at the time the act was committed, for the commission of which the prisoner now stands charged, he had that competent use of his understanding as that he knew that he was doing, by the very act itself, a wicked and wrong thing." The Chief Justice further stated that "If he was not sensible at the time he committed that act, that it was a violation of the law of God or of man, undoubtedly he was not responsible for that act, or liable to any punishment whatever flowing from that act." 9 No reference was made to the Solicitor General's test of capacity to control his act. The jury found the defendant "not guilty, on the ground of insanity."

In 1844 Abner Rogers was tried in Massachusetts for murder. ${ }^{10}$ The defense was insanity. Chief Justice Shaw of the Supreme Court, who presided at the trial, presented to the jury many tests ${ }^{11}$ for determining the responsibility of the defendant. One of these tests was the following:

the general statements of the Justice as to 'controlling disease ... which he could not resist,' than with his more specific remarks about the knowledge of right and wrong." Glueck, Mental Disorders and the Criminal Law 153 (1925).

7. The Queen v. M'Naughton, 4 St. Tr. (N.S.) 847 (1843). Counsel for the defense in his address to the jury before calling his witnesses quoted several statements from Dr. Ray's treatise, which he described as "perhaps the most scientific treatise that the age has produced upon the subject of insanity in relation to jurisprudence." Id. at 878 .

8. Id. at 924 .

9. Id. at 925 .

10. Com. v. Rogers, 7 Metc. 500 (Mass. 1844).

In State v. Thompson, Wright's Ohio Rep. 617, 622 (1834), the trial judge charged the jury that "if his mind was such, that he retained the power of discriminating, or to leave him conscious he was doing wrong, a state of mind in which at the time of the deed he was free to forbear, or to do the act, he is responsible as a sane man."

In Clark v. State, 12 Ohio Rep. 483 (1843), the trial judge put to the jury the question: "Was the accused a free agent in forming the purpose to kill Cyrus Sells?" Id. at $494 \mathrm{n}$.

11. For a discussion of these tests see Keedy, Insanity and Criminal Responsibility, 30 Harv. L. Rev. 535, 725-729 (1917). 
"If then it is proved, to the satisfaction of the jury, that the mind of the accused was in a diseased and unsound state, the question will be, whether the disease existed to so high a degree, that for the time being it overwhelmed the reason, conscience and judgment, and whether the prisoner in committing the homicide, acted from an irresistible and uncontrollable impulse: If so, then the act was not the act of a voluntary agent, but the involuntary act of the body, without the concurrence of a mind directing it." ${ }^{12}$

It will be noted that "irresistible impulse" is combined with overwhelming of the "reason, conscience and judgment." The verdict of the jury was "not guilty, by reason of insanity."

In 1846 Charles Mosler was tried in the Court of Oyer and Terminer of Philadelphia County, Pennsylvania, for first degree murder in the killing of his wife. ${ }^{13}$ Chief Justice Gibson of the Supreme Court, with two other Justices, presided at the trial. The defense was insanity. The Chief Justice in charging the jury stated inter alia the following:

"But there is a moral or homicidal insanity, consisting of an irresistible inclination to kill, or to commit some other particular offence. There may be an unseen ligament pressing on the mind, drawing it to consequences which it sees, but cannot avoid, and placing it under a coercion, which, while its results are clearly perceived, is incapable of resistance." ${ }^{14}$

The trial of M'Naughton acquired particular prominence because the "verdict, and the question of the nature and extent of the unsoundness of mind which would excuse the commission of a felony of this sort, having been made the subject of debate in the House of Lords it was determined to take the opinion of the Judges on the law governing such cases." ${ }^{15}$ The Judges were Tindal, C. J. and Coltman,

12. Com. v. Rogers, 7 Metc. 500, 502 (Mass. 1844).

13. Com. v. Mosler, 4 Pa. 264 (1846).

14. Id. at 267. The Chief Justice qualified the quoted statement as follows: "The doctrine which acknowledges this mania is dangerous in its relations, and can be recognized only in the clearest cases. It ought to be shown to have been habitual, or at least to have evinced itself in more than a single instance. It is seldom directed against a particular individual; but that it may be so, is proved by the case of the young woman who was deluded by an irresistible impulse to destroy her child, though aware of the heinous nature of the act. The frequency of this constitutional malady is fortunately small, and it is better to confine it within the strictest limits. If juries were to allow it as a general motive, operating in cases of this character, its recognition would destroy social order as well as personal safety. To establish it as a justification in any particular case, it is necessary either to show, by clear proofs, its contemporaneous existence evinced by present circumstances, or the existence of an habitual tendency developed in previous cases, becoming in itself a second nature." Ibid.

15. M'Naghten's Case, 10 Cl. \& Fin. 200, 202 (1843). Note that the name of the defendant was spelled "M'Naughton" in the report of the trial in 4 St. Tr. (N.S.) 847 (1843). 
Erskine, Maule and Cresswell, JJ. of the Court of Common Pleas; Lord Denman, C. J. and Patteson, Williams, Coleridge and Wightman, JJ. of the Court of Queen's Bench, and Lord Abinger, C. B. and Parke, Alderson, Gurney and Rolfe, BB. of the Court of Exchequer.

The Lords presented five questions to the Judges, all of whom with the exception of Maule, $\mathrm{J}^{16}$ joined in answering them. Two of the questions with the answers thereto are of importance in the present discussion. They were as follows:

"Your Lordships are pleased to inquire of us, secondly, "What are the proper questions to be submitted to the jury, where a person alleged to be afflicted with insane delusion respecting one or more particular subjects or persons, is charged with the commission of a crime (murder, for example) and insanity is set up as a defence?' And, thirdly, 'In what terms ought the question to be left to the jury as to the prisoner's state of mind at the time when the act was committed?" And as these two questions appear to us more conveniently answered together, we have to submit our opinion to be, that the jurors ought to be told in all cases . . . that to establish a defence on the ground of insanity it must be clearly proved that, at the time of the committing of the act, the party accused was labouring under such a defect of reason, from disease of the mind, as not to know the nature and quality of the act he was doing; or if he did know it, that he did not know he was doing what was wrong." 17

It is important to note two things with regard to this answer of the Judges, (1) that the questions of the Lords were specifically limited to the case of a person "afflicted with an insane delusion" ${ }^{18}$ as was M'Naughton and (2) that the test announced by the Judges was the same as that given to the jury by Tindal, C. J. in the trial of M'Naugh-

16. Maule, $J$. was of the opinion that the Judges should have declined to answer the questions of the Lords for the following reasons: (1) "They do not appear to arise out of and are not put with reference to a particular case"; (2) there was no argument on the subject of the questions; and (3) as the questions related to matters of criminal law of great importance and frequent occurrence "the answers to them by the Judges may embarrass the administration of justice, when they are cited in criminal trials." Id. at 204.

17. Id. at 209. The answers of the Judges to the questions of the Lords were given by Tindal, C. J.

18. Alexander J. E. Cockburn, who was counsel for M'Naughton, after becoming Chief Justice of the Court of Common Pleas expressed the opinion that the answers of the judges "embodied only so much of the law as sufficed to answer the specific questions that had been submitted" to them. OPpenheimer, The CRIMrNal RESPONSIBILITY of LUNATICs 26 (1909). Oppenheimer states that the opinion of Cockburn "cannot for a minute be sustained," and further states that the answers "must be taken to be a complete declaration of the whole law in 1843." Ibid.

"Surely the judges must not be presumed to have answered a question they were never asked." MERCIER, CRIMINAL ResponstBIITTY 177 (1905).

"The effect of insanity on the will could not arise on the Questions put to the judges, for such a question was not asked; the Questions refer to "insane delusion." " Barnes, $A$ Century of the McNaghten Rules, 8 CAMB. L.J. 300, 310 (1944). 
ton. It is a reasonable conclusion that if, following the Oxford case, the Lords had asked the Judges to state the test when insanity is set up as a defence they would have responded in the language employed by Lord Denman to the jury in that case, which, as already stated, was as follows: "If some controlling disease was, in truth, the acting power within him which he could not resist, then he will not be responsible." It is not likely that Lord Denman, who joined in the answers of the Judges to the questions of the Lords, would have done so if he had believed the answers related to any problem of mental disease other than "insane delusion."

\section{II}

Following the publication of the answers of the Judges to the questions of the Lords, based on the acquittal of M'Naughton, English trial judges in charging juries generally employed the test of "knowledge of right and wrong" 18 and, when the question arose, declared that irresistible impulse was not a defense. ${ }^{20}$ Writers on the Criminal Law also stated that the law was as announced by the Judges. ${ }^{21}$ However, some physicians maintained that irresistible impulse, when the product of mental disease, should be a defense. The most influential of these was Dr. Henry Maudsley, Professor of Medical Jurisprudence in the University College, London. Writing in 1874 he stated "it is a fact that in a certain state of mental disease a morbid impulse may take such despotic possession of the patient as to drive him, in spite of reason and against his will, to a desperate act of suicide or homi-

19. Reg. v. Higginson, 1 C. \& K. 129 (1843) ; Reg. v. Vaughan, 1 Cox C.C. 80 (1844); Reg. v. Layton, 4 Cox C.C. 149 (1849) ; Reg. v. Davies, 1 F. \& F. 69 (1858); Reg. v. Richards, 1 F. \& F. 87 (1858) ; Reg. v. Law, 2 F. \& F. 836 (1862) ; Reg. v. Leigh, 4 F. \& F. 915 (1866).

20. Reg. v. Barton, 3 Cox C.C. 275 (1848) ; Reg. v. Stokes, 3 C. \& K. 185 (1848); Reg. v. Haynes, 1 F. \& F. 666 (1859); Reg. v. Brough, 2 F. \& F. 838n. (1862). The trial occurred in 1854.

In Reg. v. Stokes the charge of Rolfe, B. to the jury was in part as follows: "Every man is held responsible for his acts by the law of this country, if he can discern right from wrong. This subject was, a few years ago, carefully considered by all the judges, and the law is clear upon the subject. It is true that learned speculators, in their writings, have laid it down that men, with a consciousness that they were doing wrong, were irresistibly impelled to commit some unlawful act. But who enabled them to dive into the human heart, and see the real motive that prompted the commission of such deeds?" 3 C. \& K. at 188.

In Regina v. Haynes a portion of the charge of Bramwell, B. to the jury was as follows: "But if an influence be so powerful as to be termed irresistible, so much the more reason is there why we should not withdraw any of the safeguards tending to counteract it. There are three powerful restraints existing, all tending to the assistance of the person who is suffering under such an influence-the restraint of religion, the restraint of conscience, and the restraint of law. But if the influence itself be held a legal excuse, rendering the crime dispunishable, you at once withdraw a most powerful restraint-that forbidding and punishing its perpetration." 1 F. \& F. at 667.

21. Archrold, Pleading and Evidence in Crmainal Cases 15 (13th ed. 1859); Russeli, Crimes and Misdemeanors 19 (4th ed. 1865). 
cide." 22 James Fitzjames Stephen, the most learned writer on the Criminal Law of England during the nineteenth century, published in 1883 his treatise on this subject. ${ }^{23}$ He contended that irresistible impulse should be a defense, ${ }^{24}$ and expressed the opinion that a person who acts under such an impulse does not know the nature of his act. ${ }^{25}$

In a number of reported cases during the present century the trial judge charged the jury that the defendant was not responsible if he was unable to control his action, even if he knew that it was wrong. ${ }^{26}$ The most important of these was the case of Ronald True, who was tried for murder in 1922. The trial judge told the jury that they should not convict him "even if the prisoner knew the physical nature of his act, and knew that it was morally wrong and punishable by law, and yet was from mental disease deprived of the power of controlling his actions at the time." 27 The defendant, however, was convicted, and his appeal to the Court of Criminal Appeal was dismissed. Shortly thereafter he was "certified insane." The trial and the subsequent proceedings aroused popular interest such as followed the acquittal of M'Naughton. ${ }^{28}$ As a result Lord Birkenhead, the

22. Maudsiey, Responsibility in Mental Disease 143 (1874).

23. Stephen, History of the Criminal Law of England (1883).

24. "The proposition, then, which I have to maintain and explain is that, if it is not, it ought to be the law of England that no act is a crime if the person who does it is at the time when it is done prevented either by defective mental power or by any disease affecting his mind from controlling his own conduct, unless the absence of the power of control has been produced by his own default." 2 Id. at 168 .

25. Id. at 171 .

26. Rex v. Hay, 22 Cox C.C. 268 (1911) ; Rex v. Fryer, 24 Cox C.C. 403 (1915); Rex v. Jolly, 83 Just. P. 296 (1919); Appeal of True, 16 Cr. App. R. 164 (1922). In Rex v. Hay the medical officer of Brixton Prison testified that the defendant, who was charged with feloniously shooting at the prosecuting witness with intent to murder him, "knew that he was firing a revolver and that it was wrong to do so, but that owing to disease of the mind he was unable to control the homicidal impulse which dominated him." Darling J. directed the jury that "if they believed the evidence of Dr. Dyer they would be justified in finding the prisoner guilty of the act charged, but insane at the time of committing it so as not to be responsible according to law." 22 Cox C.C. at 269.

To the same effect are Reg. v. Cockroft (1865), cited in Taylor, MEDrCAL JurIsPRUDENCE 761 (12th Am. ed. 1897) ; Reg. v. Jordan (1870), Reg. v. Gill (1883) and -Reg. v. Hay (1911), cited in Sulifvan, Crime AND INSANity 231 (1924).

In March, 1943, a young man, Lees-Smith, was tried at the Central Criminal Court, London, for the murder of his mother. The medical testimony was to the effect that, though he knew what he was doing at the time of the killing, he was unable to control the impulse to kill. Although the trial judge in charging the jury employed only the "knowledge of right and wrong test" of the M'Naghten Rules, the jury refused to convict the defendant. Following is an extract from an editorial in the Lavo Times: "This will not be the first time that juries have refused to find a verdict in accordance with the rules. If, however, this precedent is followed and scientific evidence is admitted in future trials that a prisoner, while knowing the quality of his act, is unable to control his actions, the rules will, it seems, have to be extended to include within the defence of insanity uncontrollable impulse." 195 L.T. 115 (1943).

27. 16 Cr. App, R. 164, 169 (1922).

28. Goonwin, Insanity and the Criminat 270 (1924); Sullivan, Crime and INSANITY 231 (1924). 
Lord Chancellor, appointed a Commission composed of distinguistied lawyers and judges, ${ }^{29}$ who had had extensive experience in the administration of the Criminal Law. Lord Justice Atkin was chairman of the Commission, which was directed "to consider what changes, if any, are desirable in the existing law, practice and procedure relating to criminal trials in which the plea of insanity as a defence is raised."

The British Medical Association presented to the Commission a recommendation that the existing law be retained with "a modification as to lack of control." 30 After careful consideration of this recommendation the Commission reported that "It was established to our satisfaction that there are cases of mental disorder where the impulse to do a criminal act recurs with increasing force until it is, in fact, uncontrollable." ${ }^{31}$ The Commission accordingly made the following recommendation :

"It should be recognized that a person charged criminally with an offence is irresponsible for his act when the act is committed under an impulse which the prisoner was by mental disease in substance deprived of any power to resist. It may require legislation to bring this rule into effect." 32

The Government having declined to proceed on the recommendation of the Commission, Lord Darling introduced in the House of Lords a bill embodying the recommendation. ${ }^{33}$ The bill was, however, rejected after Lord Sumner, Lord Hewart (the Lord Chief Justice), Viscount Haldane (the Lord Chancellor), Lord Dunedin and Viscount Cave spoke in opposition to it.

Lord Sumner said that he would accept the opinion of the medical men, who came before the Commission, that there are cases where there exists an uncontrollable impulse due to disease of the mind. ${ }^{34}$

29. The members of the Commission were Lord Justice Atkin (Chairman), Sir Ernest Pollock, Sir Leslie Scott, Sir Herbert Stephen, Bart., Sir Richard Muir, Sir Archibold Bodkin, Sir Edward Troup, Sir Ernley Blackwell and Sir Edward Marshall-Hall. Rep. Comm. on Insanity and Crime, CMd. No. 2005, 2 (1923).

30. Id. at 4. The Medico-Psychological Association presented to the Commission the following recommendation: "The legal criteria of responsibility expressed in the rules in McNaghten's case should be abrogated and the responsibility of a person should be left as a question of fact to be determined by the jury on the merits of the particular case." Ibid. The Commission did not approve this recommendation.

31. Id. at 8. The Commission further stated the following: "The suggested rule postulates mental disease; and we think it should be made clear that the law does recognize irresponsibility on the ground of insanity where the act was committed under an impulse which the prisoner was, by mental disease, in substance deprived of any power to resist." Ibid.

32. Id. at 21. Other proposals for legislative change of the existing law regarding insanity as a defense are set forth in Davies, Irresistible Impulses in English Laze, 17 CAN. B. REv. 147 (1939).

33. 57 H.L. Deb. 443 (5th ser. 1924).

34. Id. at 457 . 
He stated, however, that he was convinced there were not many such cases and that no injustice had resulted from the application of the existing law, while on the other hand grave results would follow if the proposed bill became law. ${ }^{35}$

Lord Hewart stated that the Court of Criminal Appeal had "expressly repudiated" the doctrine of uncontrollable impulse. ${ }^{36}$ With regard to the proposal of Lord Darling's bill he stated that he had consulted twelve of the judges of the King's Bench Division, who are also judges of the Court of Criminal Appeal, and that "ten are, like myself, emphatically opposed to this measure, one is emphatically in favor of it and one is doubtful." ${ }^{37}$ He added that if the proposal of the Commission was adopted "it would be impossible to distinguish between the impulse of the person said to be suffering from mental disease, and the impulse of the ordinary offender who is moved to commit a crime by the desire for gain or revenge." 38

Viscount Haldane expressed the opinion that while the proposal was "abstractly right" it would put too much burden on the jurors. He then stated the following: "Let your Lordships dismiss from your minds the fear that anybody who has acted under an uncontrollable impulse, which he can not resist when he commits the crime, is likely to be hanged." 40 Lord Dunedin said that the passage of the bill "would open the door to subterfuge and impede the proper carrying out of the criminal law." 41 Viscount Cave stated that "Where there is a compelling impulse of that kind it is always taken into account either by the Judge at the trial or, in the event of conviction, by the Secretary of State when he comes to consider the sentence." $42 \mathrm{He}$ also said that if the bill became law it "will make irresistible an impulse which now is resistible and resisted because of the penal law." 43

It will be noted that three of the Lords, Sumner, Haldane and Cave, who spoke in opposition to the bill, recognized the existence in some cases of an irresistible impulse, the product of mental disease, notwithstanding the fact that the Court of Criminal Appeal, as stated by Lord Hewart, repudiated the doctrine of irresistible impulse. ${ }^{44}$ The

35. Id, at 459 .

36. $I d$. at 467 ,

37. $I d$. at 465 .

38. Id. at 468 .

39. $I d$. at 471 .

40. Id. at 472 .

41. Id. at 475 .

42. $I d$. at 476 .

43. Ibid. (1922).

44. Id. at 467. See Hewart, L.C.J. in Appeal of True, 16 Cr. App. R. 164, 170 
practice has frequently not been in accordance with this holding. Judges in their instructions to the jury have sometimes stated that it is a defense, and in many cases, where the trial judge has charged that the defendant is responsible unless he met the test of not knowing right from wrong, the jury has refused to convict. This statement is supported by convincing authority.

Lord Justice Atkin, the Chairman of Lord Birkenhead's Commission, stated the following: "In practice, the judge, the counsel, the jury, the witnesses and all concerned were desirous, in cases of uncontrollable impulse, to acquit the accused on the ground of insanity." 45

Lord Chancellor Haldane in discussing Lord Darling's bill stated: "I have never heard of these Rules [M'Naghten's Case] embarrassing any Judge who really had a case before him in which justice required an acquittal, or preventing him from giving such direction to a jury as would enable them to apply these Rules in cases where they ought to be applied, in cases, for instance, where the impulse was so dominant as to deprive a person of freedom or of any realization of what he was doing." 46

G. Ellenbogen, who, as stated at the beginning of this article, contends that irresistible impulse should not affect criminal responsibility, states that "It must be admitted that because the Crown can not appeal from an acquittal (and that is the effect of the verdict 'guilty, but insane') a vast number of cases-as is evident from the newspaper reports-are disposed of far more leniently than a strict application of the Macnaghten rules could possibly permit." 47

The author of a carefully considered article in the Cambridge Law Journal made the following statement:

"This dislike [of the existing law] now appears to have spread to juries, judging by the verdicts of guilty but insane, returned at the Central Criminal Court in 1936 and 1943, in the face of the McNaghten Rules. If juries persist in recognizing the defence of irresistible impulse, the legislature or the Courts may be forced through pressure of public opinion to recognize it as well." 48

A learned legal writer, the Principal of Brasenose College, Oxford, has presented the following statistical information:

45. Atkin, L.J. Insanity as a Defence in Murder Cases, 159 L.T. 435, 436 (1925).

46. 57 H.L. DEB. 474 (5th ser. 1924).

47. Ellenbogen, The Principles of the Criminal Law Relating to Insanity, $1 \mathrm{~J}$. CRIM. Scr. 178, 190 (1948). Permission to include this quotation was granted by the editors.

48. Barnes, A Ceniury of the McNaghten Rules, 8 CANs. L.J. 300, 321 (1944). Permission to include this quotation was granted by the author and the editor. 
"Statistics show that between 1901 and 1922 of 1445 persons sent to trial for murder 485 or about 34 per cent. were found insane. No one can suppose that the 485 satisfied the tests imposed by the rules in M'Naghten's Case." 49

Other authorities are set forth in the footnotes. ${ }^{50}$

It may, therefore, be concluded that while irresistible impulse, abstractly considered, is not a part of the English criminal law, in practice it frequently constitutes a defense.

In Scotland, around the middle of the nineteenth century, the trial judges in charging the jury ordinarily laid down the "knowledge of right and wrong" test. ${ }^{51}$ However, in 1855 Lord Justice Clerk Hope told a jury that "men of common sense, and acquainted with the ordinary actions of mankind, not taking up any particular views on insanity whatever, but acting upon the dictates of their good sense, are far better judges than either medical men or lawyers as to that state of mind which should exempt a man from liability for a criminal act." 52 In 1874 Lord Justice Clerk Moncrief stated to a jury the following:

"A man may be entirely insane, and yet may know well enough that an act which he does is forbidden by law. Probably a large proportion of those who occupy our asylums are in that position. It is not a question of knowledge, but of soundness of mind." 53

Even more significant is a portion of the charge given to a jury by Lord Justice General Dunedin in 1907, which was as follows:

49. Stallybrass, A Comparison of the General Principles of Criminal Lawe in England with the "Progetto Definitivo di un Nuovo Codice Penale" of Alfredo Rocco in The Modern Approach to Criminal Law 390, 416 (Radzinowicz and Turner ed. 1945). Permission to include this quotation was quoted by the editors.

50. "In cases where there is evidence of real mental disease antecedent to the commission of the alleged crime, and there is no evidence of a motive which might influence a sane person, juries have no difficulty in finding either that the accused did not appreciate the nature of his act or that he did not know it was wrong." Lord Sumner, in discussion of Lord Darling's bill, 57 H.L. DEB. 468 (5th ser. 1924). To same effect Mr. Travers Humphrey at a joint meeting of the Cambridge University Medical Society and the Cambridge University Law Society, 1 CAMB. L.J. 302, 309 (1923).

"In practice, therefore, the legal doctrine of criminal responsibility has been innocuous : it has not produced its logical conseqences, because it has never been fully applied." Sullivan, Crime and Insanity 230 (1924). To the same effect MacNiven, Psychoses and Criminal Responsibility in MENTAL ABNORMaLITY AND CRIME 8, 70 (Radzinowicz and Turner ed. 1944).

51. H.M. Adv. v. Gibson, 2 Broun 332, 355 (1844) ; H.M. Adv. v. Yates, Ark. 238, 241 (1847); H.M. Adv. v. Wylie, 3 Irv. 218, 234 (1858); H.M. Adv. v. McFadyen, 3 Irv. 650, 664 (1860).

52. H.M. Adv. v. Smith and Campbell, 2 Irv. 1, 61 (1855).

53. H.M. Adv. v. Miller, 3 Coup. 16, 18 (1874). 
"It is quite certain that what may be called scientific opinion on insanity has greatly altered in recent years, and Courts of law, which are bound to follow, as far as they can, the discoveries of science and the results of experience, have altered their definitions and rules along with the experts. . . . But Acts of Parliament can not deal with scientific opinions, and therefore it is left to juries to come to a common-sense determination on the matter, assisted by the evidence led and any direction which the Judge can give." 54

The last sentence would seem to explain why Lord Dunedin, who became a Lord of Appeal in 1913, opposed Lord Darling's bill in the House of Lords. ${ }^{55}$

In 1925 a judge of the High Court of Justiciary sitting with a jury in a homicide case instructed them that "The question, accordingly, which you have to determine is whether, at the time of the accident, the accused was or was not master of his own action." ${ }^{56}$ The verdict was not guilty. A distinguished Glasgow psychiatrist, writing in 1944, stated that it is "the practice in the Scottish Courts to ignore the McNaghten Rules." 57

In South Africa the Courts of the Cape of Good Hope and Transvaal after discussing the answers of the Judges in M'Naghten's Case expressly adopted the test of irresistible impulse..$^{58}$

The six states of the Commonwealth of Australia divide evenly on the question whether irresistible impulse is a defense. Queensland and Western Australia have identical statutes which provide that there is no criminal responsibility when the defendant was in "such a state of mental disease . . . as to deprive him of capacity to control his actions. . . ." 59 The Tasmanian Code provides that a person is not responsible when the act was done "under an impulse which, by reason of mental disease, he was in substance deprived of any power

54. H.M. Adv. v. Brown, [1907] Sess. Cas. 67, 77.

55. See page 964 , supra.

56. Lord Murray in H.M. Adv. v. Ritchie, [1926] J.C. 45, 49 (1925).

57. MacNiven, Psychoses and Criminal Behaviour in MENTAL ABNoRMaluty and CRIME 8, 59 (Radzinowicz and Turner ed. 1944).

58. The Supreme Court of the Cape of Good Hope laid down the rule that "the defence of insanity is established if it be proved that the accused had, by reason of such mental disease, lost the power of will to control his conduct in reference to the particular act charged as an offence." Queen v. Hay, 16 Cape of Good Hope (S.C.) 290, 301 (1899).

The Chief Justice of the Supreme Court of Transvaal in charging a jury stated "that though a man may have committed an act which, if an ordinary man had done it would have entailed criminal consequences, yet if the jury are satisfied that by reason of mental disease he could not resist the impulse under which he acted, then he is not criminally liable." Rex v. Smit [1906] Transvaal (S.C.) 783, 785. (1902).

59. Queensland: CrRM. CODE §27 (1899). Western Australia: CrIM. CoDE §27 
to resist." 60 The courts of New South Wales, ${ }^{61}$ South Australia ${ }^{62}$ and Victoria apply the "knowledge of right and wrong" test, and exclude irresistible impulse.

A decision of the Court of Criminal Appeal of Victoria in the case of Rex $v$. Sodeman ${ }^{63}$ in 1936 aroused considerable interest. The Court refused to allow an appeal from a conviction based on a charge of the trial judge following the rule of M'Naghten's Case. The defendant applied to the High Court of Australia for leave to appeal, contending that the trial judge erred in not telling the jury that they should acquit "if disease of the mind deprived the prisoner of all control.". The four judges of the High Court, who heard the appeal, divided evenly and consequently the application for leave to appeal was refused. ${ }^{64}$ The two judges who voted not to allow the appeal relied on the decisions of the English Court of Criminal Appeal. One of the judges who favored allowing the appeal based his opinion on the recommendation of Lord Atkin's Commission in 1923, and used the following forceful language regarding the decisions of the English Court of Criminal Appeal: "It would be unsatisfactory if the common law of England, of which the rule of M'Naughten's Case is a part, must be regarded as forever unable to adjust its rules to modern medical knowledge and science, and this merely as a result of the decision of a Divisional Court in England, the rulings of which are not considered necessarily authoritative by the House of Lords." 65

On a petition to the Privy Council for "special leave to appeal" the decision was that "their Lordships will therefore humbly advise His Majesty to dismiss the petition." ${ }^{68}$ The Lord Chancellor in his opinion stated that if a different rule from that of the Court of Criminal Appeal should be adopted "the effect would be that there would be different standards of law prevailing in England and the Dominions." 67 It is interesting to compare this pronouncement with the state of the law on this point in Queensland, Tasmania, Western Australia, Cape of Good Hope and Transvaal, already presented in this article. An Australian lawyer, commenting on the Sodeman case said: "There is, in Australia, however, as there seems to be in other countries which derive their concepts from the English criminal law, a marked reluc-

60. Tasmania: CRIM. CODE $\$ 16$ (1924).

61. Rex v. Green, 25 N.S.W. W.N. 93 (1908).

62. Barnes, $A$ Century of the McNaghten Rules, 8 Caмв. L.J. 300, 318 (1944).

63. Rex v. Sodeman [1936] V.L.R. 99.

64. Sodeman v. The King, 55 Com. L.R. 192 (1936).

65. Id at 227 .

66. Id. at 234 .

67. Id. at 232 . 
tance to face the problems to which a realistic approach to the question of criminal responsibility give rise." 68

Irresistible impulse is not recognized in Canada nor New Zealand. The Canadian Criminal Code of 1906 contains a section codifying the "knowledge of right and wrong" test ${ }^{69}$ and the courts in subsequent cases have disapproved irresistible impulse. ${ }^{70}$ In one case the trial judge, in charging the jury said "The law says to men who say they are afflicted with irresistible impulses: 'If you can not resist an impulse in any other way, we will hang a rope in front of your eyes, and perhaps that will help." "71 In a New Zealand case the jury was told it was not ground for acquittal that the defendant "suffered from an impulse which he could not control." 72

The Criminal Code of India, adopted in 1860, incorporated the "knowledge of right and wrong" test. ${ }^{73}$ The High Court in a well considered opinion in 1906 stated that this rule might be applied as well to extreme cases "where insanity affects the offender's will and emotions as to those where it affects his cognitive faculties, because where the will and emotions are affected by the offender being subjected to insane impulses, it is difficult to say that his cognitive faculties are not affected." 74

\section{III}

In thirteen European countries the penal codes specifically provide that lack of volition under certain named conditions may negative criminal responsibility.

France: "There is neither crime ${ }^{75}$ nor délit, ${ }^{76}$ when the defendant was in a state of insanity at the time of his act or was impelled by a 439 (1943).

68. Barry, Insanity in the Criminal Law of Australia, 21 Can. B. Rev. 429,

69. Canada: Crim. Code $\S 19(1)$ (1907).

70. The King v. Creighton, 14 Can. Crim. Cas. 349 (1908); Rex v. Jessamine, 21 Ont. W.R. 392, 4 Ont. W.N. 753 (1912).

71. Riddell, $J$. in the King v. Creighton, supra note 70, at 350. See Meredith, Insanity as a Criminal Defence: $A$ Conflict of Views, 25 CAN. B. Rev. 251 (1947).

72. Reg. v. Deighton, 18 N.Z. 891 (1900).

73. India: Penal Code $\$ 84$ (5th ed. 1910).

74. Queen-Empress v. Kader Nasyer Shah, 23 India 604, 608 (Calcutta Ser. 1896). The Court based its statement on 2 Stephen, History of THE CRIMINaI. LAW OF ENGLAND 167 (1883).

75. Serious offense.

76. Offense of the middle grade. There are three grades of offenses in Francecrime, délit and contravention. Keedy, The Preliminary Investigation of Crime in France, 88 U. of PA. L. REv. 385, 389 (1940). 
force which he was not able to resist." 77 A similar provision occurs in the codes of Belgium ${ }^{78}$ and Luxemburg. ${ }^{78}$

Germany: "An act does not constitute an offense if the actor at the time of the commission of the act was either unable to realize the forbidden nature of his act or unable to act in accordance with proper understanding because his consciousness was impaired or because he has suffered either pathological mental derangement or mental infirmity." 80

Italy: "One who has the capacity to intend and to will is responsible." 81

Switzerland: "One is not punishable who, being afflicted with a mental disease, idiocy, or a serious derangement of conscience, does not have at the moment of acting the ability to understand the illegal nature of his act nor to decide in accordance with this understanding." 82

Poland: "No penalty attaches to one who at the time of acting, by reason of lack of mental development, mental disease or other derangement of the mental faculty, is not able to understand the significance of his act nor to control his conduct." 83

Turkey: "A person is not punishable who at the time he committed the act was in a state of mental derangement sufficient to take away his perception or the freedom of his actions." 84

Soviet Republics: "Measures of social defense of a judicialcorrectional character are not applicable to persons having committed offenses in a state of chronic mental disease or of temporary derange-

77. France: Penal Code Ans. bk. II, art. 64 (1952). A substantially similar provision occurs in Egypt: PeNAL Code tit. I, c. IX, $\$ 62$ (1937).

78. Belgium: Penal Code bk. I, art. 71 (1947).

79. Luxemburg: PeNaI CoDe bk. I, c. VIII, § 71 (1900).

80. Germany: Criminal Code pt. I, §51 (English trans. 1947).

The corresponding provision of the Criminal Code of the German Empire, enacted in 1871 was as follows: "An act does not constitute an offense if the actor at the time of its commission was in a state of lack of consciousness or pathological mental derangement by which the free exercise of his will was excluded." $\$ 51$ (English trans. 1947).

The phrase "unable to act in accordance with proper understanding" in the new Code has the same meaning as "the free exercise of his will was excluded" in the Imperial Code. The Statutory Criminal Law of Germany 44, Comment (1946), prepared by the Library of Congress.

81. Italy: Penal Code bk. I, tit. IV, art. 85 (1930).

82. Switzerland: Penal Code ANn. pt. I, tit. II, art. 10 (1951).

83. Poland: Penal Code ANv. c. II, art. 17, \$1 (1932, French trans. 1927).

84. Turkey: Penal Code bk. I, tit. IV, art. 46 (1926, French trans. 1927). 
ment of mental activity or in any other state of disease, if such persons are not able to understand their actions nor to control them." 85

Hungary: "One is not responsible who did the act in a mental condition or state of unconsciousness which deprived him of the ability to understand the social danger of his action or to act according to his will." 88

Czechoslovakia: "A person is not criminally responsible for his act if at the time of this act, being mentally deranged, he was not able to discern that his act was dangerous to society or could not control his actions." 87

Bulgaria: "An act is not considered a crime if committed by a person, who because of his retarded mental development, or permanent or temporary disorder of consciousness was not able to understand the nature and significance of his act or to control his actions." 88

Greece: "An act will not be imputed to a person when at the time he committed it, due to a diseased derangement of his intellectual faculties or derangement of his conscience, he lacked the ability to understand the illegality of his actions or to act according to such understanding." 80

Yugoslavia: "A person committing a criminal offence in a state of lasting or temporary mental disease, temporary mental derangement or defective mental development is not criminally liable inasmuch as owing

85. Soviet Republics: PENAI Code tit. III, art. 11 (1926, French trans. 1935). See Berman and Hunt, Crininal Law and Psychiatry: The Soviet Solution, 2 STAN. L. Rev. 635, 640-642 (1950); Killian and Aarons, Use of Psychiatry in Soviet Crintinal Proceedings, 41 J. Crim. L. AND CRIMInology 136, 143-145 (1950).

"A criminal act is not considered a crime if committed by a person who at the time of committing it could not understand the nature and significance of his action or control his actions because of a morbid disturbance of his mental activity, or of unconsciousness or in consequence of a cause depending on a physical defect or an illness, or defective mental development." Estonia: PENAL CoDE $\$ 39$ (1929). Translated into Russian by Mr. Egon Sild, an Estonian lawyer. English translation by Dr. Anthony Salys, Ass't Professor of Slavic Philology, University of Pennsylvania.

A similar provision was included in the Penal Code of Latvia $\$ 39$ (German trans. 1933).

86. Hungary: Penal CoDE c. II, § 10-1 (1950). This section was translated by Dr. Paul Gyorgy of the Medical Faculty of the University of Pennsylvania.

87. Czechoslovakia: PeNal Code art. 11 (1951, French trans.). Salys.

88. Bulgaria: Penal Code $\S 13$ (1951). This section was translated by Dr.

89. Greece, Penal Code art. 34 (1950). This article was translated by Dr. Michael Dorizas, Ass't Professor of Geography, University of Pennsylvania. The earlier Greek Code made "ability to reason" the test of criminal responsibility. Greece, Penal Code art. 86 (1930). 
to such a state of mind he was unable to understand the significance of his act or control his conduct." 90

The penal codes of Denmark, ${ }^{91}$ Finland, ${ }^{92}$ Netherlands, ${ }^{93}$ Norway, ${ }^{94}$ Portugal, ${ }^{95}$ Roumania, ${ }^{96}$ Spain ${ }^{97}$ and Sweden ${ }^{98}$ provide, in slightly different wording, that a person suffering from mental disease is not criminally responsible. In Denmark "the court may find, on the basis of medical evidence, that a state of irresistible impulse is quite analogous to that of insanity and falls within the legal concept of irresponsibility in the sense of art. 16 of the Danish Penal Code, even though the offender knew that he was doing wrong; however the court is not bound to do so, and in most cases the offender will be punished, though most likely with a reduced penalty." 99 Irresistible impulse is not a defense in Finland, but may be taken into account by the court in assessing the penalty. ${ }^{100}$ Swedish law does not recognize the "concept of irresistible impulse." 101 In Roumania it was decided in one

90. Yugoslavia: Penal Code art. 6 (1951, English trans.). See Donnelly, The New Yugoslav Criminal Code, 61 YALE L.J. 510 (1952).

The corresponding provision of the Penal Code of 1929 was as follows: "One is not responsible who at the time the act was committed was not able to understand the nature and character of his act nor to act according to such understanding because of mental derangement or confused reasoning or lack of intellectual development or feeble-mindedness." PeNAI CODE $\$ 22$ (1929). This section was translated by Dr. Alfred Senn, Professor of Germanic and Baito-Slavic Philology in the University of Pennsylvania.

91. "An act is not punishable when committed by a person who is irresponsible by reason of mental disease." Denmark: Penal Code c. $3, \$ 16$ (1949).

92. "An act committed by one who is insane is not punishable." Finland: PENAL CODE c. $3, \S 3(1920)$.

93. "A person is not punishable who commits an act for which he is not responsible because of derangement of his mental capacity due to disease." Netherlands: PENAL CODE bk. I, tit. 3, art. 37 (1949).

94. "An act is not punishable if the actor was mentally diseased." Norway: Penal Code c. $3, \S 44$ (1929).

95. "Insane persons who do not have lucid intervals are not responsible for a crime." Portugal: PENAL CoDe c. 4, art. 42, 2 (1930).

96. "It is not considered a crime or délit if the act was committed in a state of insanity or any other state causing loss of the use of reason through causes independent of one's will." Roumania: PENAL CODE art. 57 (1930). This article was translated by Dr. George O. Seiver, Professor of Romance Languages in the University of Pennsylvania.

97. "Exempt from criminal responsibility are: An insane person and one who is in a state of mental disturbance, unless this state was caused intentionally in order to commit an offense." Spain: PeNAL CoDE bk. I, tit. I, c. 2, art. 8 (1944).

98. "There is no responsibility for an act committed under the influence of mental disease." Sweden: Penal Cone c. 5, § 5 (LAws of the Realas, 1949). The above provisions of the codes of Denmark, Finland, Netherlands, Norway and Sweden were translated by Dr. Thorsten Sellin, Professor of Sociology in the University of Pennsylvania.

99. Letter to the writer from Dr. Knud Waaben, Secretary in the Ministry of Justice, Copenhagen, Feb. 15, 1952.

100. Letter to Professor Sellin from Dr. Inkeri Anttila, Docent of Criminal Law and Criminology, University of Helsinki, Feb. 20, 1952.

101. Letter to Professor Sellin from Professor Ivar Strahl, Professor of Criminal Law, University of Uppsala, Feb. 5, 1952. 
case that an epileptic impulse constituted a defense. ${ }^{102}$ No judicial interpretations of the code provisions of Netherlands, Norway, Portugal and Spain was obtained.

The Supreme Court of the Irish Free State discussed the question of irresistible impulse in two cases. In a case decided in $1935^{103}$ counsel for the defendant contended that the trial judge should have charged the jury that this was a defense. The court decided that the judge's failure so to charge was proper as there was no evidence to support such a defense. Kennedy, C. J., however, after stating "the Rule in M'Naghten's Case" said:

"The scientific exploration of mental diseases has in modern times been pursued with results to knowledge not contemplated at a time not very remote from the present. A vast area of research and discovery lies in the relatively short period of time between Hogarth's cartoon of Bedlam and current theories as to the upsetting of the glandular balance of the human body." 104

The Chief Justice also stated the following: "No doubt, substantial grounds of objection in practice may be raised against admitting the defence of 'irresistible impulse', but, the English Court of Criminal Appeal to the contrary notwithstanding, that is not sufficient to rule it out of consideration, if it be shown to rest on any established principles of the criminal law." 105

In a case in 1937 the Court decided that it was proper for the judge not to charge on irresistible impulse as there was no evidence that such a condition of mind was present. It was, however, stated that "In so deciding, this Court does not express any opinion on the question whether, if irresistible impulse had been established, it would afford any defence to the charge." 108

\section{IV}

In Siam the Penal Code contains the following section: "A person shall not be punished for any act done by him if at the time it is done he is prevented either by defective mental power or by any disease affecting his mind from appreciating the nature or illegality of his act or from controlling his conduct." 107

102. Penal Code art. 57, n. 2 (1930).

103. Att'y Gen. v. O'Brien [1936] Ir. 263 (1935).

104. Id. at 269.

105. $I d$. at 271.

106. Sullivan, C. J. in Att'y Gen. v. Boylan [1937] Ir. 449, 461 (1937).

107. Siam: Penal Code $\$ 46$ (1907, Official English trans.). 
In Japan the Code provision is "An act of a person of unsound mind is not punishable." 108 The question whether an irresistible impulse, without accompanying incapacity to understand the difference between right and wrong, is a defense has not been decided by the courts, but "according to the prevailing theory among Japanese criminal law professors an irresistible impulse is a defense" under the section of the Penal Code set forth above. ${ }^{109}$ The Chinese Penal Code provides that "an act committed by an insane person is not punishable." 110

The Penal Code of the Philippine Islands provides that "an imbecile or lunatic, unless the latter has acted during a lucid interval" is exempt from criminal responsibility. ${ }^{111}$ This provision has been applied literally and the defendant held irresponsible where the testimony showed that he was insane when he acted. ${ }^{112}$

\section{$\mathrm{V}$}

Ten Latin-American countries provide in their penal codes that lack of volition may negative criminal responsibility.

Argentina: "One is not punishable who at the time he acted was not able because of defect or morbid disturbance of his faculties . . . to understand the criminal character of his act nor to control his actions." 118

Brazil: "One is exempt from punishment when, at the time of acting, by reason of mental disorder or retarded mental development, he was entirely unable to understand the criminal character of his action or to act in accordance with this understanding." 114

Costa Rica: "One is exempt from punishment who, due to a derangement of his mental faculties at the time of his act, was incapable of understanding the criminal character of his act or of controlling his actions." 115

108. Japan: Crminal Code, art. 39 (1947, English trans. 1950).

109. Letter to the writer from Dr. Shigemitsu Dando, Professor of Criminal Law, University of Tokio, Dec. 6, 1951.

110. China: Penal Code art. 19 (1935 French trans.).

111. Philippine Islands: PeNal Code bk. I, tit. I, c. I, art. 8, 1 (1929).

112. "We are convinced that the accused was a lunatic when he committed the grave felony described in the record and that consequently he is exempt from criminal liability, and should be confined in an insane asylum." Malcolm, J. in People v. Bascos, 3 Phil. 204, 207 (1922).

113. Argentina: Penal Cone bk. I, tit. V, art. 34(1).

114. Brazil : Penal Code tit. III, art. 22.

115. Costa Rica: Penal Code bk. I, tit. II, c. III, art. 25 (3). 
Dominican Republic: "No offense has been committed if at the time of committing the act, the person was, without his fault, in a state of insanity, or impelled by a force which he could not resist." 110

Ecuador: "No one can be punished for an act, regarded by the law as an infraction, if he did not commit it voluntarily and consciously." 117

Haiti: "There is no criminal offense if the accused was in a state of insanity at the time he acted or was impelled by a force which he could not resist." 118

Panama: "One will not be liable to punishment who commits a wrongful act at a time when his mental faculties are deranged or confused due to illness causing lack of judgment or of consciousness and freedom of action." 119

Peru: "One is exempt from punishment who commits a criminal act in a state of mental disease, idiocy, or serious derangement of his consciousness and does not have, at the time of acting, sufficient capacity to understand the criminal character of his act or to control it according to this understanding." 120

Uruguay: "A person is not responsible when at the time the act was committed by reason of a physical, mental, constitutional or acquired illness or by intoxication he was in such a state of mental derangement that he was not capable, or only partially capable, of understanding the illegal character of his act or of controlling, it according to a correct understanding." 121

Venezuela: "A person is not punishable when he commits an act in a state of mental disease sufficient to deprive him of consciousness or freedom of action." 122

In contrast with the foregoing the Penal Code of Puerto Rico provides that "a morbid propensity to commit prohibited acts by a person, whose incapacity to understand the wrongful character of such acts can not be proven, may not be set up as a defense for such acts." 123

116. Dominican Republic: Penal Code bk. II, art. 64.

117. Ecuador: Penac Code bk. I, tit. III, art. 32.

118. Haiti: Penal Code bk. III, c. I, art. 48.

119. Panama: Penal Code bk. I, tit. IV, art. 44.

120. Peru: Penal Code bk. I, tit. $X$, art. $85(1)$.

121. Uruguay: Penal Code bk. I, tit. II, c. II, art. 30.

122. Venezuela: Penal Code bk. I, tit. V, art. 62.

123. Puerto Rico: Penal Code tit. III, §39(4).

The above citations were taken from Jnafnez de Asúa, Códigos Penales IBEROAMERICANOS (1946). 
In Bolivia, ${ }^{124}$ Chile, ${ }^{125}$ Colombia, ${ }^{126}$ Cuba, ${ }^{127}$ Guatemala, ${ }^{128}$ Honduras, ${ }^{129}$ Mexico, ${ }^{130}$ Nicaragua, ${ }^{131}$ Paraguay ${ }^{132}$ and El Salvador, ${ }^{133}$ the penal codes provide in general terms that an insane person can not be criminally responsible. The courts of Colombia, ${ }^{134}$ Honduras ${ }^{135}$ and Mexico ${ }^{136}$ recognize irresistible impulse as a defense. In Paraguay it is not a defense, but the courts may consider it in assessing the penalty. ${ }^{137}$ No interpretation of the code provision in the other countries listed in this paragraph was obtained.

\section{VI}

In the states of this country the law regarding insanity as a defense is found both in statutes and in the decisions of the courts. During the nineteenth century, starting with Georgia in 1817, statutes were passed in sixteen states providing in substance that an insane person can not commit a crime. In Georgia, Illinois and Colorado, the statute states that "A lunatic or insane person, without lucid intervals, shall not be found guilty of any crime or misdemeanor with which he may be charged, provided the act so charged as criminal was

124. Bolivia: "state of insanity." PeNAL CoDe bk. I, tit. I, art. 13(2).

125. Chile: "the lunatic or insane person unless he has acted during a lucid interval." PeNAL Code bk. I, tit. I, par. II, art. 10(1). art. 29.

126. Colombia: "state of mental derangement." PeNAL Code bk. I, tit. I, c. II,

127. Cuba: "insane person and one who at the time of committing the offense was in a state of mental derangement although of a transitory nature." CoDE oF Social DeFense bk. I, tit. III, c. II, art. 35 (A).

128. Guatemala: "insane person and one who was in a state of transitory mental derangement, unless this condition was caused intentionally." PENAL CODE bk. I, tit. I, par. II, art. 21(1).

129. Honduras: "the imbecile and lunatic unless he acted during a lucid interval." Penal Code bk. I, tit. I, c. II, art. 7(1).

130. Mexico: "involuntary mental derangement of pathological and transitory character." PENAL CODE bk. I, tit. I, c. IV, art. 15(II).

131. Nicaragua: "lunatic and insane person unless he acted during a lucid interval." PENAL CoDE bk. I, tit. I, c. IV, art. 21 (1).

132. Paraguay: "those who commit the offense under the influence of mental disease which deprives them of the use of their mental faculties." PENAL CODE bk. I, sec. I, c. III, art. $18(3)$.

133. El Salvador: "the lunatic or insane person, unless he acted during a lucid interval and one who for any cause, independent of his will, is completely deprived of his reason." Penal CoDe bk. I, tit. I, c. II, art. 8(1).

The above citations were made from Jiménez dE Asúa, Códigos Penales IBEROAMERICANOS (1946).

134. Letter to Carlos Berguido, Jr., Esq., of the Philadelphia Bar, from Dr. Efraín Calero Mercado of Cali, Dec. 27, 1951.

135. Letter to Mr. Berguido from Dr. Jorge Fidel Durón, Rector of the University of Honduras, Dec. 10, 1951. $19,1951$.

136. Letter to Mr. Berguido from Lic. Rómulo Becerra of Mexico City, Dec.

137. Letter to Mr. Berguido from Dr. César Acosta of Asunción, Jan. 30, 1952. 
committed in the condition of such lunacy or insanity"; ${ }^{138}$ while in Arkansas there is a similar statute without the proviso. ${ }^{130}$ In all these states except Georgia the courts have approved the test of irresistible impulse. ${ }^{140}$

The statute in California, Utah, Arizona, Idaho and Montana provides that "All persons are capable of committing.crimes except . . . lunatics and insane persons"; ${ }^{141}$ while the Minnesota statute is phrased "lunatics or insane persons are incapable of committing crimes."142 Utah is the only one of these states which has expressly approved irresistible impulse, ${ }^{143}$ while language of the Supreme Court of Montana seems to approve it. ${ }^{144}$ California, Arizona and Minnesota have disapproved it. ${ }^{145}$ In Idaho the courts have not passed

138. Ga. Penal Code div. I, $\$ 5$ (1817) ; Code $\$ 26-303$ (1933).

Ill. Crim. Code \$ 5 (1827) ; ANN. Stat. c. 38, §592 (1935).

Colo. Crim. Code $\$ 5$ (1868); Stat. Ann. c. 48, \$5 (1935).

139. Ark. Stat. c. 44, §5 (1838); Stat. AnN. \$41-108 (1947).

140. People v. Krauser, 315 IIl. 485, 146 N.E. 593 (1925) ; People v. Nierstheimer, 401 Ill. 260, 81 N.E.2d 900 (1948). See discussion of cases prior to 1917 in Keedy, Insanity and Criminal Responsibility, 30 HARv. L. REv. 535, 732-735 (1917).

Ryan v. People, 60 Colo. 425, 153 Pac. 756 (1915) ; Oldham v. People, 61 Colo. 413, 158 Pac. 148 (1916).

Green v. State, 64 Ark. 523, 43 S.W. 973 (1898) ; Bell v. State, 120 Ark. 530, 180 S.W. 186 (1915) ; Hankins v. State, 133 Ark. 38, 201 S.W. 832 (1917) ; Sease v. State, 155 Ark. 130, 244 S.W. 450 (1922); Travis v. State, 160 Ark. 215, 254 S.W. 464 (1923); Korsak v. State, 202 Ark. 921, 154 S.W.2d 348 (1941). Georgia does not recognize irresistible impulse as a defense unless it results from a delusion.

Roberts v. State, 3 Ga. 310 (1847) ; Flanagan v. State, 103 Ga. 619, 30 S.E. 550 (1898) ; Rozier v. State, 185 Ga. 317, 195 S.E. 172 (1938).

141. Cal. Act to Amend Penal Code $\$ 2$ (1874) ; Penal Code pt. I, tit. I, $\S 26$ (1949).

Utar Penal Code $\$ 22$ (1876); Code Ann. \$103-1-40 (1943).

Ariz. Penal Code pt. I, tit. I, § 30-3 (1887); Code ANn. § 43-114 (1939).

IDAmo Ter. Rev. Stat. \$6330 (1887); Code ANN. \$18-201 (1947).

Mont. Penal Code pt. I, tit. I, § 30-3 (1895) ; Rev. Codes AnN. \$ 94-201 (1947).

142. Mrnn. Penal Code $\S 18$ (1886); Stat. $\$ 610.08$ (1949).

143. State v. Green, 78 Utah 580, 6 P.2d 177 (1931). The opinion of Hansen, J. contains a comprehensive discussion of the subject.

144. "It therefore follows that one may have mental capacity and intelligence sufficient to distinguish between right and wrong with reference to the particular act, and to understand the consequence of its commission, and yet be so far deprived of volition and self control by the overwhelming violence of mental disease that he is not capable of voluntary action, and therefore not able to choose the right and avoid the wrong." Brantly, C.J. in State v. Peel, 23 Mont. 358, 369, 59 Pac. 169, 173 (1899). Approved in State v. Keer1, 29 Mont. 508, 517, 75 Pac. 362, 365 (1904) and in State v. Leakey, 44 Mont. 354, 370, 120 Pac. 234, 239 (1911).

145. People v. Hoin, 62 Cal. 120 (1882) ; People v. Ward, 105 Cal. 335, 38 Pac. 945 (1894); People v. Hubert, 119 Cal. 216, 51 Pac. 329 (1897); People v. Owens, 123 Cal. 482, 56 Pac. 251 (1899) ; People v. Morisawa, 180 Cal. 148, 179 Pac. 888 (1919); People v. Walter, 7 Cal.2d 438, 60 P.2d 990 (1936).

Judd v. State, 41 Ariz. 176, 16 P.2d 720 (1932).

State v. Scott, 4 Minn. 365, 43 N.W. 62 (1899) ; State v. Simenson, 195 Minn. 258, 262 N.W. 638 (1935). See note, 17 MINN. L. Rev. 630 (1933). 
on the exact question, but have announced the "knowledge of right and wrong" test. ${ }^{146}$

The corresponding provision of the statute in New York, Texas, Nevada, South Dakota, and Oklahoma is "An act done by a person in a state of insanity can not be punished as a public offense." 147 Nevada in 1912 also adopted the provision that "All persons are liable to punishment . . . except lunatics and insane persons." 148 Texas has disapproved irresistible impulse. ${ }^{149}$ In Nevada the exact question has not arisen, but the Supreme Court has approved the "knowledge of right and wrong" test. ${ }^{150}$

Without repealing the statute exempting insane persons from criminal liability, New York, Minnesota, South Dakota and Oklahoma enacted two provisions, the first stating, with varying wording, that an insane person is liable unless he was unable to distinguish between right and wrong ${ }^{151}$ and the second specifically stating that "A morbid propensity to commit prohibited acts existing in the mind of a person who is not shown to have been incapable of knowing that such acts were wrong shall constitute no defense." 152 Without any previous enactment North Dakota adopted the "right and wrong" provision, ${ }^{153}$ and

146. People v. Walter, 1 Idaho 386 (1871) ; State v. Larkins, 5 Idaho 200, 47 Pac. 945 (1897) ; State v. Wetter, 11 Idaho 433, 83 Pac. 341 (1905) ; State v. Fleming, 17 Idaho 471, 106 Pac. 305 (1910).

147. N.Y. REv. STat. vol. II, pt. IV, tit. VII § 2 (1829); Penal Law $\$ 1120$ (1944).

Tex. Penat Code art. 41 (1857); Penal Code Anv. art. 34 (1938).

NEV. TER. LAWS c. CIV, \$571 (1861); CoMp. LAWS ANN. \$11183 (1929). S.D. Penal Code \$ 8833 (1899); Code \$34-2001 (1939).

OKLa. Stat. \$5807 (1890); Stat. tit. $22, \S 1161$ (1941).

148. Nev. Rev. Laws $\S 6268$ (1912); Comp. Laws ANN. $\$ 9952$ (1929).

149. Hurst v. State, 40 Tex. Cr. 378, 50 S.W. 719 (1899); Cannon v. State, 41 Tex. Cr. 467, 56 S.W. 351 (1900); Thomas v. State, 55 Tex. Cr. 293,116 S.W. 600 (1909); Hogue v. State, 65 Tex. Cr. 539, 146 S.W. 905 (1912); Carnes v. State, 101 Tex. Cr. 273, 275 S.W. 1002 (1925); Langhorn v. State, 105 Tex. Cr. 470, 289 S.W. 57 (1926).

150. State v. Lewis, 20 Nev. 333, 22 Pac. 241 (1889) ; State v. Hartley, 22 Nev. 342, 40 Pac. 372 (1895). In a later case the trial court told the jury that "before the defendant can be excused on the ground of insanity the jury must believe from the evidence that the defendant at the time of the commission of the crime was without sufficient reason to know what he was doing, or that, as the result of mental unsoundness, he had not sufficient will power to govern his action by reason of some insane impulse which he could not resist or control." The Supreme Court in affirming the conviction expressed no opinion regarding the correctness of this charge. State v. Clancy, 38 Nev. 181, 147 Pac. 449 (1915).

151. N.Y. LAws vol. III, c. 676, \$21 (1881); PENAL LAW $\$ 1120$ (1944).

Minn. Penai Code \$19 (1886); Stat. 610.10 (1949).

S.D. Penal Code \& 7465 (1889); Code $\$ 13-0201$ (1939).

OkLa. Stat. \$1863 (1890); STat. tit. $21 \$ 152$ (1941).

152. N.Y. Laws vol. III, c. 676 \$23 (1881); PENAL LAW \$34 (1944).

Minn. Penal Code $\$ 21$ (1886); Stat. 610.09 (1949).

S.D. Penal CoDe $\$ 7467$ (1889); Code $\$ 13.0505$ (1939).

OkLa. Stat. \$1865 (1890); Stat. tit. 21 \& 154 (1941).

153. N.D. REv. CoDEs $\S 6814$ (1895) ; REv. CODE $\$ 12-0201$ (1943). 
Oregon the one relating to "morbid propensity." 154 The courts of New York, Minnesota, and Oklahoma, which, as already stated, have both the "right and wrong" and "morbid propensity" provisions, have disapproved irresistible impulse. ${ }^{155}$ It is a reasonable conclusion that a similar decision will be made in South Dakota when the question arises. The defense has been rejected in Oregon, ${ }^{\mathbf{1 5 6}}$ and probably will be in North Dakota.

By way of summary it may be stated that in the states which during the nineteenth century adopted statutes on insanity as a test of liability Arkansas, Colorado, Illinois and Utah recognize irresistible impulse, while Arizona, California, Georgia, Minnesota, New York, Oklahoma, Oregon and Texas have disallowed it. In Idaho and Nevada the "knowledge of right and wrong" test has been approved. It is remarkable that except in a very few cases the courts in reaching a decision made no mention of the existing statute or statutes. In the doubtful states Montana seems to favor the test, while it will probably be disallowed in Idaho, North Dakota and South Dakota.

The Supreme Court of Louisiana in 1904 inferentially approved the test of irresistible impulse. ${ }^{167}$ However, in 1942 the Legislature enacted a statute embodying the "knowledge of right and wrong" rule. ${ }^{158}$ When the question arises again it is likely that the court, if it adverts to the statute, will not approve irresistible impulse.

In the states which do not have statutes on insanity as a defense the irresistible impulse test has been approved in Alabama, ${ }^{159}$ Con-

154. Ore. Crim. Code $\$ 729$ (1864); Comp. Laws ANN. \$23-122 (1940).

155. Flanagan v. People, 52 N.Y. 467 (1873) ; People v. Waltz, 50 How. Pr. 204 (1874); People v. Carpenter, 102 N.Y. 238, 6 N.E. 584 (1886).

For Minn. citations see note 145 supra.

Sloan v. State, 25 Okla. Cr. 15, 218 Pac. 717 (1923); Tittle v. State, 44 Okla. Cr. 287, 280 Pac. 865 (1929); Merrick v. State, 56 Okla. Cr. 88, 34 P.2d 281 (1934); Hoggatt v. State, 67 Okla. Cr. 377, 94 P.2d 264 (1939).

156. State v. Hassing, 60 Ore. 81, 118 Pac. 195 (1911); State v. Grayson, 126 Ore. 560, 270 Pac. 404 (1928) ; State v. Wallace, 170 Ore. 60, 131 P.2d 222 (1942). See Williamson, The Insanity Defense, 1 ORE. L. REv. 100 (1922).

157. State v. Lyons, 113 La. 959, 37 So. 890 (1904).

158. LA. Acts no. 43, art. 14 (1942) ; REV. STAT. tit. XIV, c. 1, § 14 (1950).

159. Somerville, J., in the famous case of Parsons v. State announced the following rule: "(1) If, by reason of the duress of such mental disease, he had so far lost the power to choose between the right and wrong, and to avoid doing the act in question, as that his free agency was at the time destroyed. (2) And if, at the same time, the alleged crime was so connected with such mental disease, in the relation of cause and effect, as to have been the product of it solely." 81 Ala. 577, 597, 2 So. 854,866 (1886).

The above rule of Parsons v. State was approved in Wingard v. State, 247 Ala. 488, 25 So.2d 170 (1946).

Before Parsons v. State was decided the Supreme Court of Alabama had stated insanity was not a defense unless "the accused was not conscious that in doing the particular act he was committing a crime against the laws of God and his country." Dargan, C. J. in McAllister v. State, 17 Ala. 434, 437 (1850). 


\section{necticut, ${ }^{160}$ Delaware, ${ }^{161}$ Indiana, ${ }^{162}$ Kentucky, ${ }^{163}$ Massachusetts, ${ }^{164}$ Michigan, ${ }^{165}$ Vermont, ${ }^{166}$ Virginia ${ }^{167}$ and Wyoming. ${ }^{168}$ It has been}

160. In a first degree murder case the trial judge charged the jury "That if the prisoner was laboring under some controlling disease, which was an active power within him, which he could not resist, then he was not responsible." The Supreme Court stated that "We think the charge of the court upon the subject of insanity was unexceptionable." Carpenter, J. in State v. Johnson, 40 Conn. 136, 142 (1873).

161. In 1851 the trial judge in a murder case, where insanity was set up as a defense, instructed the jury that "the question is not how much reason and judgment a man has, but whether he had at the time the ability to distinguish between right and wrong in reference to the act itself, and the power to choose whether he would do it or not." Harrington, J. in State v. Windsor, 5 Harr. 512, 539 (Del. 1856). The judge also quoted the following from Lord Denman's charge to the jury in Reg. v. Oxford, 9 C. 8 P. 525 (1840): "If some controlling disease was in truth the acting power within him, which he could not resist, then he will not be responsible." 5 Harr. at 540.

A similar charge was given in State v. Reidell, 9 Houst. 470, 472, 14 At1. 550, 551 (Del. 1888) and State v. Jack, 4 Penne. 470, 475, 58 Atl. 833, 834 (Del. 1903).

162. Stevens v. State, 31 Ind. 485 (1869) ; Bradley v. State, 31 Ind. 492 (1869); Goodwin v. State, 96 Ind. 550 (1884); Plake v. State, 121 Ind. 433, 23 N.E. 273 (1890) ; Morgan v. State, 190 Ind. 411, 130 N.E. 528 (1921).

In 1888 a trial judge instructed the jury that "If he [defendant] was laboring under an irresistible, uncontrollable mental delusion, impelling him to do said act, that he was at the time of the perpetration of said killing in such a state of mind as to be unable to control his will and his actions in regard to the act so committed, in judgment of law he was insane." The Supreme Court decided that this instruction "correctly stated the law as it has been heretofore enunciated by this court." Coffey, J. in Grubb v. State, 117 Ind. 277, 288, 20 N.E. 725, 726 (1888).

163. Scott v. Com., 4 Met. 227 (Ky. 1863) ; Abbott v. Com., 107 Ky. 624, 55 S.W. 196 (1900) ; Jolly v. Com., 110 Ky. 190, 61 S.W. 49 (1901) ; Cline v. Com., $248 \mathrm{Ky} .609,59$ S.W.2d 577 (1933); Sharp v. Com., $308 \mathrm{Ky} .765,215$ S.W.2d 983 (1948).

164. Com. v. Rogers, 7 Metc. 500 (Mass. 1844) ; Com. v. Johnson, 188 Mass. 382 , 74 N.E. 939 (1905) ; Com. v. Cooper, 219 Mass. 1, 106 N.E. 545 (1914); Com. v. McCann, 325 Mass. 510, 91 N.E.2d 214 (1950). The Rogers, Johnson and Cooper cases are discussed in Keedy, Insanity and Criminal Responsibility, 30 HARv. L. Rev. $535,724-730$ (1917).

165. "The law has no theories on the subject of insanity. It holds every one responsible who is compos mentis, or a free agent, and every one irresponsible who is non compos mentis, or not having control of his mind." Campbell, C. J. in People v. Finley, 38 Mich. 482, 483 (1878).

In People v. Durfee, 62 Mich. 487, 29 N.W. 109 (1886), the Supreme Court approved the following charge to the jury: "If by reason of disease, the defendant was not capable of knowing he was doing wrong in the particular act, or if he had not the power to resist the impulse to do the act by reason of disease or insanity, that would be an unsound mind."

To the same effect are People v. Quimby, 134 Mich. 625, 96 N.W. 1061 (1903) and People v. Bowen, 165 Mich. 231, 130 N.W. 706 (1911).

166. Doherty v. State, 73 Vt. 380, 50 At1. 113 (1901), State v. Kelley, 74 Vt. 278, 52 Atl. 434 (1902).

167. Dejarnette v. Com., 75 Va. 867 (1881) ; Thurman v. Com., 107 Va. 912, 60 S.E. 99 (1908).

168. "The court very properly, we think, called the attention of the jury to the distinction between an act committed by reason of insanity which destroyed the will power, and an act committed as the result of uncontrolled passion not the result of disease." Beard, J. in Flanders v. State, 24 Wyo. 81, 156 Pac. 39, 43 (1916). 
disapproved in Florida, ${ }^{169}$ Iowa, ${ }^{170}$ Kansas, ${ }^{171}$ Maine, ${ }^{172}$ Maryland, ${ }^{173}$ Mississippi, ${ }^{174}$ Missouri, ${ }^{175}$ Nebraska, ${ }^{176}$ New Jersey, ${ }^{177}$ North Caro-

169. Davis v. State, 44 Fla. 32, 32 So. 822 (1902); Collins v. State, 88 Fla. 578, 102 So. 880 (1925); Crews .v. State, 143 Fla. 263, 196 So. 590 (1940).

170. In 1868 Dillon, C. J. of the Supreme Court stated the following: "But if, from the observation and concurrent testimony of medical men who make the study of insanity a specialty, it shall be definitely established to be true, that there is an unsound condition of the mind-that is, a diseased condition of the mind, in which, though a person abstractly knows that a given act is wrong, he is yet by an iisane impilse, that is, an impulse proceeding from a diseased intellect, irresistibly driven to commit it-the law must modify its ancient doctrines and recognize the truth, and give to this condition, when it is satisfactorily shown to exist, its exculpatory effect." State v. Felter, 25 Iowa 67,82 (1868).

The Chief Justice further said: "The jury, in substance, should be told that if the defendant's act in taking the life of his wife (if he did take it), was caused by mental disease or unsoundness, which dethroned his reason and judgment with respect to that act, which destroyed his power rationally to comprehend the nature and consequences of that act, and which, overpowering his will, irresistibly forced him to its commission, then he is not amenable to legal punishment." Id. at 83. It will be noted that under this test both inability to comprehend the act and an irresistible impulse are required in order that the defendant may not be amenable to puinshment.

The instruction suggested by Dillon, $C$. $J$. was approved in a number of cases. State v. Bruce, 48 Iowa 530 (1878); State v. George, 62 Iowa 682, 18 N.W. 298 (1884). However, in a case decided in 1904, where the trial court employed the double test of inability to understand the act and irresistible impulse the Supreme Court reversed the conviction, stating "Proof of either condition would entitle him to an acquittal." State v. McGruder, 125 Iowa 741, 749, 101 N.W. 646, 648 (1904). To the same effect see State v. Wegener, 180 Iowa 102, 162 N.W. 1040 (1917). In 1928 these two cases were in effect overruled, the Supreme Court approving the following instruction: "In order to be an excuse and defense for a criminal act, the person accused and who claims insanity as a defense must prove that the crime charged was caused by mental disease or unsoundness which dethroned, overcame, or swayed her reason and judgment with respect to that act, which destroyed her power rationally to comprehend the nature and consequences of that act, and which overpowering her will, irresistibly forced her to its commission." State v. Buck, 205 Iowa 1028, 219 N.W. 17 (1928).

See interesting note discussing the Iowa cases and approving the test of irresistible impulse. 32 IowA L. REv. 714 (1947).

In a recent case the Supreme Court approved the holding in State v. Buck and stated the following: "We are committed to the "right and wrong" test for insanity, and to the exclusion of the 'irresistible impulse' theory. 'Irresistible impulse' can be a factor under our decisions when, and only when, it so operates upon a diseased mind as to destroy the comprehension of consequences; it is not, in and of itself, a defense." Thompson, J. in State v. Beckwith, 46 N.W.2d 20, 30 (Iowa 1951).

171. State v. Nixon, 32 Kan. 205, 4 Pac. 159 (1884); State v. Mowry, 37 Kan. 369, 15 Pac. 282 (1887); State v. Arnold, 79 Kan. 533, 100 Pac. 64 (1909); State v. White, 112 Kan. 83, 209 Pac. 660 (1922).

172. State v. Knight, 95 Me. 467, 50 Atl. 276 (1901). Whitehouse, J. quoted with approval the following statement of the court in State v. Harrison, $36 \mathrm{~W}$. Va. 729, 15 S.E. 982 (1892): "For myself I can not see how a person who rationally comprehends the nature and quality of an act, and knows that it is wrong and criminal, can act through irresistible innocent impulse." $95 \mathrm{Me}$. at 478, 50 At1. at 279.

173. The irresistible impulse test was expressly repudiated and the "right and wrong" test adopted in Spencer v. State, $69 \mathrm{Md}$. 28, 13 At1. 809 (1888). The rule of this case was approved in Deems v. State, 127 Md. 624, 96 Atl. 878 (1915) and Taylor v. State, 187 Md. 306, 49 A.2d 787 (1946).

174. Cunningham v. State, 56 Miss. 269 (1879) ; State v. Smith, 95 Miss. 786, 49 So. 945 (1909); Eatman v. State, 169 Miss. 295, 153 S.W. 381 (1934).

175. State v. Pagels, 92 Mo. 300, 4 S.W. 931 (1887); State v. Miller, 111 Mo. 542, 20 S.W. 243 (1892) ; State v. Soper, 148 Mo. 217,49 S.W. 1007 (1899); State v. Riddle, 245 Mo. 451,150 S.W. 1044 (1912); State v. Jackson, 346 Mo. 474, 142 S.W.2d 45 (1940). In State v. Jackson the court stated that "we do not recognize 
lina, ${ }^{178}$ South Carolina, ${ }^{179}$ Tennessee, ${ }^{180}$ Washington ${ }^{181}$ and Wiscon-
sin. $^{182}$ In New Mexico, ${ }^{183}$ Ohio, ${ }^{184}$ Pennsylvania ${ }^{185}$ and West Vir-

the defense of 'volitional insanity' (meaning that although the accused can distinguish between right and wrong, still he is unable because of mental disease to resist the impulse to commit the criminal act)." Ellison, P.J. at 481, 142 S.W.2d at 49 . In a case decided just two weeks after State v. Jackson the Supreme Court approved an opinion by Cooley, J. in which he said "The doctrine of 'irresistible impulse' as an excuse or defense for crime, at least unless due to a diseased mind-in effect, insanity-is not recognized in Missouri." State v. West, 346 Mo. 563, 570, 142 S.W.2d 468, 472 (1940). (Emphasis added).

176. Schwartz v. State, 65 Neb. 196, 91 N.W. 190 (1902) ; Shannon v. State, 111 Neb. 457, 196 N.W. 635 (1923); Torske v. State, 123 Neb. 161, 242 N.W. 408 (1932); Fisher v. State, 154 Neb. 166, 47 N.W.2d 349 (1951).

177. State v. Spencer, 21 N.J.L. 196 (1846); Genz v. State, 59 N.J.L. 488, 37 Atl. 69 (1896); Mackin v. State, 59 N.J.L. 495, 36 At1. 1040 (1897); State v. Carrigan, 93 N.J.L. 268, 108 Atl. 315 (1919); State v. Noel, 102 N.J.L. 659, 133 Atl. 274 (1926); State v. Cordasco, 2 N.J. 189, 66 A.2d 27 (1949).

178. State v. Brandon, 53 N.C. 463 (1862) ; State v. Cooper, 170 N.C. 719, 87 S.E. 50 (1915) ; State v. Terry, 173 N.C. 761, 92 S.E. 154 (1917); State v. Shackleford, 232 N.C. 299,59 S.E.2d 825 (1950) semble.

The Special Committee on Crime and Psychiatry of the North Carolina Bar Association in 1951 made the following recommendation: "The presently accepted legal test of insanity-the capacity to distinguish right from wrong-is an adequate test of mental disease affecting the reasoning faculties, but it shonld be extended to include diseases which destroy will-pozer and volition and capacity to control one's conduct. Many hospitalized insane can distinguish right from wrong, but what renders them socially irresponsible is their lack of power to control their conduct along rational lines." Gardner, Insanity as a Defense in The North Carolina Criminal Lave, 30 N.C.L. REV. 4, 25 (1951).

179. State v. Bundy, 24 S.C. 439 (1885) ; State v. Alexander, 30 S.C. 74, 8 S.E. 440 (1888); State v. Levelle, 34 S.C. 120, 13 S.E. 319 (1891); State v. Gilstrap, 205 S.C. 412, 32 S.E.2d 163 (1944) ; State v. Gatlin, 208 S.C. 414, 38 S.E.2d 238 (1946). 180. Wilcox v. State, 94 Tenn. 106, 28 S.W. 312 (1894); Davis v. State, 161 Tenn. 23, 28 S.E.2d 993 (1930); Temples v. State, 183 Tenn. 531, 194 S.W.2d 332 (1946).

181. In 1930 the Supreme Court stated the following: "Insanity in law covers more than the relation of the person and the particular act which is the subject of judicial investigation. The legal problem must resolve itself into the inquiry whether there was mental capacity, or moral freedom, to do or abstain from doing the particular act." Holcomb, J. in State v. Schafer, 156 Wash. 240, 252, 286 Pac. 833, 838 (1930).

In 1948 the Supreme Court expressly disapproved irresistible impulse as a test. Referring to the rule laid down in State v. Schafer, supra, Jeffers, J. said: "We are unable to believe that, by the language last quoted from the Schafer case, this court intended to depart from the right and wrong test, thereinbefore announced." State v. Maish, 29 Wash.2d 52, 58, 185 P.2d 486, 489 (1947). This case was approved in State v. Odell, 227 P.2d 710 (Wash. 1951). See criticism of State v. Maish in Hoedemaker, "Irresistible Impulse" as a Defense in the Criminal Law, 23 WASH. L. REV. 1 (1948).

182. Oborn v. State, 143 Wis. 249, 126 N.W. 737 (1910). However, in two earlier cases the court approved a charge to the jury which included as a defense the condition where "his will, by which is meant the governing power of his mind, has been otherwise than voluntarily so completely destroyed that his actions are not subject to it, but are beyond his control." Butler v. State, 102 Wis. 364, 78 N.W. 590 (1899) and Lowe v. State, 118 Wis. 641, 96 N.W. 417 (1903).

183. In a first degree murder case the trial judge instructed the jury that "although he was conscious of the act he was doing and knew its consequences, but was in consequence of his insanity wrought up to such a frenzy as rendered him incapable and unable to control his actions or direct his movements, then you are instructed that the defendant will not be legally responsible for his acts and you will in that case acquit him." The Supreme Court held this instruction erroneous saying, "There are conditions of insanity without doubt, which deprive the will of its normal governing power, yet fall far short of amounting to 'frenzy' in the ordinary acceptance of 
ginia, ${ }^{186}$ the expressions of opinion by the courts are so conflicting that

that word." Abbott, J. in Territory v. Kennedy, 15 N.M. 556, 562, 110 Pac. 854, 856 (1910).

In 1936 the Supreme Court stated the following: "We have not departed from the 'right and wrong' test as established in the famous McNaughten Case, 10 Clark and F. 199, which is the generally accepted doctrine of the English and American courts. The capacity of the accused to distinguish right from wrong in respect to the act charged as a crime at the time of its commission is made the test of his responsibility." Zinn, J. in State v. Roy, 40 N.M. 397, 404, 60 P.2d 646, 650 (1936).

In 1938 the Supreme Court after laying down the "right and wrong" test, as stated in State v. Roy, supra, added the following: "There may, indeed, be insane impulses which are so far uncontrollable that there is no criminal liability therefor, but they must be shown to be the result of a diseased mind." Zinn, J. in State v. Moore, 42 N.M. 135, 158, 76 P.2d 19, 33 (1938).

184. The Supreme Court of Ohio was the first appellate court in this country to recognize lack of control as a defense. In 1843 the Court approved the following tests: "Was the accused a free agent in forming the purpose to kill Cyrus Sells? Was he, at the time the act was committed, capable of judging whether that act was right or wrong? And did he know at the time that it was an offence against the laws of God and man?" Clark v. State, 12 Ohio Rep. 483, 494 n. (1843).

In 1853 Corwin, J. speaking for the Supreme Court said: "And I have no doubt that every correct definition of insanity either expressly or by necessary construction, must suppose freedom of will, to avoid a wrong, no less than the power to distinguish between the wrong and the right." Farrer v. State, 2 Ohio St. 54, 70 (1853).

The Supreme Court in 1872 approved the tests laid down in Clark v. State, supra, Blackburn v. State, 23 Ohio St., 146, 165 (1872).

In 1942 the Court of Appeals for Cuyahoga County expressly disapproved irresistible impulse as a test. State v. Cumberworth, 69 Ohio App. 239, 43 N.E.2d 510. The court in reaching this conclusion made no reference to the decisions of the Supreme Court, but relied upon the answers of the Judges in M'Naghten's case; State v. Harrison, 36 W. Va. 729, 15 S.E. 982 (1892); People v. Hubert, 119 Cal. 216, 51 Pac. 229 (1897) and an article by Professor Waite, Irresistible Impulse and Criminal Liability, 23 Mír. L. REv. 443 (1925).

In 1948 the Supreme Court, without making reference to State v. Cumberworth, supra, stated the following: "We can find nothing in the record and we have searched diligently which suggests that appellant did not know right from wrong and did not have the ability to choose the right and abjure the wrong in respect to the crime he committed." Turner, J. in State v. Frohner, 150 Ohio St. 53, 117, 80 N.E.2d 868, 898 (1948). It seems likely that, when the question again arises in the Supreme Court, it will adhere to its former holdings.

185. In 1846 Chief Justice Gibson made his famous statement to the jury in Com. v. Mosler, $4 \mathrm{~Pa}$. 264 (1846). The Chief Justice stated the following at p. 267: "But there is a moral or homicidal insanity, consisting of an irresistible impulse to kill, or to commit some other particular offence. There may be an unseen ligament pressing on the mind, drawing it to consequences which it sees but can not avoid, and placing it under a coercion, which while its results are clearly perceived, is incapable of resistance."

The Chief Justice then qualified this statement with the following: "The doctrine which acknowledges this mania is dangerous in its relations, and can be recognized only in the clearest cases. It ought to be shown to have been habitual or at least to have evinced itself in more than a single instance. . . . To estabish it as a justification in any particular case, it is necessary either to show, by clear proofs, its contemporaneous existence evinced by present circumstances, or the existence of a habitual tendency developed in previous cases, becoming in itself a second nature." Ibid.

A similar instruction without the qualifications was given to the jury in later cases. Allison, $J$. in Com. v. Shurlock, 14 Leg. Intel. 33 (Pa. 1857); Allison, J. in Com. v. Smith, 6 Am. L. Reg. 257, 267 (Pa. 1858); Allison, J. in Com. v. Freeth, 6 Am. L. Reg. 400, 404 ( $\mathrm{Pa}$ 1858); Brewster, J. in Com. v. Winnemore, 1 Brewst. 356, 367 (Pa. 1867). 
it is impossible to state with any degree of certainty what is the law on the subject. The Supreme Court of Rhode Island has never decided

The Supreme Court expressly approved irresistible impulse in Coyle v. Com., $100 \mathrm{~Pa} .573,578$ (1882) and Taylor v. Com., $109 \mathrm{~Pa} .262,270$ (1885). In Com v. DeMarzo, $223 \mathrm{~Pa} .573,575,72$ At1. 893 (1909) the Supreme Court in a Per Curiam opinion said "The power to distinguish between right and wrong is not always the only test of responsibility, since this power may exist without the power of selfcontrol."

In 1925 Shaffer, J. speaking for the Supreme Court stated the following: "If there has been any departure from the wise rule which makes the test of the accused's responsibility, his ability to distinguish between right and wrong, it has been surrounded at all times with the restrictions imposed by Chief Justice Gibson when sitting in the court of oyer and terminer in Com. v. Mosler, $4 \mathrm{~Pa}$. 264." Justice Shaffer then quoted the qualifications made by Chief Justice Gibson, which are set forth supra. Com. v. Cavalier, $284 \mathrm{~Pa}$. 311, 320, 131 Atl. 229, 233 (1925).

In 1930 the trial judge in a murder case charged that irresistible impulse was a defense. The defendant, however, was convicted and appealed. On the appeal counsel for the appellant cited Com. v. Cavalier, supra, for the proposition that the "defense of irresistible impulse was recognized by our courts" while counsel for the Commonwealth cited the same case to uphold the opposite contention. Com. v. Shroeder, 302 Pa. 1, 3, 152 Atl. 835 (1930).

The conviction was affirmed and Com. v. Cavalier was approved. Shaffer, J. also added the dictum: "The court should have told the jury that the defense of irresistible impulse is one which one law does not recognize." Supra at 10, 152 At1. at 837.

In Com. v. Szachewicz, 303 Pa. 410, 154 At1. 483 (1931), no question of insanity was raised but Kephart, J. stated the following: "We have held that our test for insanity, as it relates to crime, is his ability to distinguish between right and wrong: Taylor v. Com. $109 \mathrm{~Pa} .262$. Persons are not below par, subnormal, or mentally deficient in judgment, in determinative or discriminative power or in self-control, when considered in relation to criminal acts, if they know the difference between right and wrong." $303 \mathrm{~Pa}$. at 416,154 Atl. at 484 . It has already been pointed out that the Supreme Court approved the test of irresistible impulse in Taylor v. Com., cited supra by Justice Kephart.

In Com. v. Lockard, 325 Pa. 56, 60, 188 At1. 755, 757 (1937), Drew, J. stated "The test of insanity in this jurisdiction, as it relates to crime, is the ability to distinguish between right and wrong: Commonwealth v. Szachewicz, $303 \mathrm{~Pa} .410 . "$

In a case decided in 1949 Justice Stern stated the following: "Apart from the fact that 'confusional insanity' is apparently an antiquated and discarded theory and that the proposition that there could be such a thing as a momentary insanity was sharply challenged by a witness for the Commonwealth, it would seem quite obvious that defendant's witness failed to differentiate between a mere temporary frenzy or emotional excitation, and insanity within the legal meaning of that term, namely inability, from disease of the mind, to understand the nature and quality of the act and to distinguish between right and wrong with respect to it: Commonwealth v. Szachewicz, $303 \mathrm{~Pa}$. 410, 416, 417, 154 At1. 483, 484, 485; Commonwealth v. Lockard, $325 \mathrm{~Pa}$. 56, 60188 Atl. 755, 757. Certainly neither social maladjustment, nor lack of control, nor impulsiveness, nor psycho-neurosis, nor emotional instability, nor chronic malaria, nor all of such conditions combined, constitute insanity within the criminal-law conception of that term." Com. v. Neill, $362 \mathrm{~Pa} .507,513,514,67$ A.2d 276, 279, 280 (1949).

In twa cases in the Federal Court for the Western District of Pennsylvania the judge in 1950 cited Com. v. Neill in support of the following rule:

"In order for insanity to be a legal defense to the commission of a crime there must be:

(a) Such a perverted and deranged condition of the mental and moral faculties as to render person incapable of distinguishing between right and wrong; or

(b) he must be unconscious and unaware at the time of the nature of the act he is committing; or

(c) where, though conscious of it and able to distinguish between right and wrong and know that the act is wrong, yet his will, or the governing pozer of his mind, has been othererise than voluntarily, so completely destroyed that his actions 
the question, but in 1904 stated the right and wrong test "has been criticized as not entirely accurate." ${ }^{187}$ In New Hampshire there is no special test, the Supreme Court having held that in every case where mental disease is set up as a defense the question is whether the defendant had the requisite mens rea. ${ }^{188}$ A summary of the law in each state is set forth in a footnote..$^{189}$

The Federal Courts approve irresistible impulse as a defense ${ }^{190}$ and it is included in the new Manual for Courts Martial. ${ }^{101}$

are not subject to it, but are beyond his control." Gourley, J. in U.S. ex rel. Herge v. Com. of Pa., 89 F. Supp. 636, 640 (1950) and U.S. ex rel. Wing v. Com. of Pa. et al., $90 \mathrm{~F}$. Supp. 208, 211 (1950). (Emphasis added).

186. On October 11, 1892, the Supreme Court in an opinion by Brannon, J. expressly and emphatically repudiated the irresistible impulse test. Brannon, J. stated the following: "For myself I can not see how a person who rationally comprehends the nature and quality of an act, and knows that it is wrong and criminal, can act through irresistible innocent impulse." State v. Harrison, 36 W. Va. 729, 751, 15 S.E. 982,990 (1892).

On the same day that State v. Harrison was decided, Holt, J. speaking for the Court, stated the following: "If there were any evidence showing or tending to show an irresistible insane impulse, as distinguished from the ordinary case of an impulse not resisted, that the killing was the direct result of the destruction by insanity of the power of self-control, then the counsel for the accused should have called on the court for an instruction directed specially to that point." State v. Maier, 36 W. Va. 757, 771, 15 S.E. 991,996 (1892).

In 1911 the Supreme Court stated: "There is no evidence that the frenzy or ungovernable passion, the irresistible impulse of the prisoner, on the night of the homicide, on hearing the confessions of his wife, was the result of mental disease, as distinguished from weakness or passion." Miller, J. in State v. Cook, 69 W. Va. 717, 722 , 72 S.E. 1025, 1027 (1911). This statement was quoted with approval by Litz, J. in State v. Evans, 94 W. Va. 47, 55, 117 S.E. 885, 887 (1923).

187. State v. Quigley, 26 R.I. 263, 270, 58 Atl. 905,907 (1904).

188. State v. Pike, 49 N.H. 399 (1869), State v. Jones, 50 N.H. 369 (1871).

189. Summary: Irresistible impulse is approved in Alabama, Arkansas, Colorado, Connecticut, Delaware, Illinois, Indiana, Kentucky, Massachusetts, Michigan, Montana, Utah, Vermont, Virginia, Wyoming (15). It is disapproved in Arizona, California, Florida, Georgia, Iowa, Kansas, Maine, Maryland, Minnesota, Mississippi, Missouri, Nebraska, New Jersey, New York, North Carolina, Oklahoma, Oregon, South Carolina, Tennessee, Texas, Washington and Wisconsin (22). The decisions are conflicting in New Mexico, Ohio, Pennsylvania and West Virginia (4). The "right and wrong" test has been approved, but the question of irresistible impulse as a defense has not been decided, in Idaho, Nevada, North Dakota, Rhode Island and South Dakota (5). In Louisiana there is doubt, but a recent statute laying down the "right and wrong" test will probably be interpreted as excluding irresistible impulse. New Hampshire rejects all the "symptom tests" and applies simply the requirement of imens rea.

The courts which hold that irresistible impulse, resulting from mental disease, is a defense differentiate this condition from an emotional impulse produced by anger, hatred or jealousy. See Rowe v. State, 243 Ala. 618, 11 So.2d 749 (1943) ; Bell v. State, 120 Ark. 530, 180 S.W. 186 (1915); Ryan v. State, 60 Colo. 425, 153 Pac. 756 (1915) ; Plake v. State, 121 Ind. 433, 23 N.E. 273 (1889); Flanders v. State, 24 Wyo. 81, 156 Pac. 1121 (1916).

190. Instructions laying down the rule of irresistible impulse were approved by the Supreme Court in Davis v. United States, 165 U.S. 373 (1897); Matheson v. United States, 227 U.S. 540 (1913) ; Fisher v. United States, 328 U.S. 463 (1946). The Court of Appeals for the District of Columbia reversed a conviction because the trial judge refused to instruct the jury that irresistible impulse was a defense. Smith v. United States, 36 F.2d 548 (D.C. Cir. 1929).

191. MANUAL FOR CoURTS-MARTIAL 200 (1951). See discussion of this provision in Legal aNd Legislative Basis of Manual for Courts-Martial 166, 167 (1951). See also pamphlet, Psychiatry in Miritary Law, Arary Technical Manual 8-240 and AIR Force Manual 160-42 (1950). 


\section{VII}

It is a fundamental principle of the criminal law that volition is a requisite element of every crime. ${ }^{192}$ The chief reason for this requirement is that without volition there can be no act. ${ }^{103}$ It is also stated that criminal intent requires volition. ${ }^{104}$ Since an impulse, if irresistible,

192. Blackstone stated "the concurrence of the will, when it has its choice either to do or to avoid the fact in question, being the only thing that renders human actions either praiseworthy or culpable." 4 Comm. 20 (1769).

"The offender must have been "able to help" his conduct." CLARk, Elements of CRIMINAI LIABILITY 109 (1880).

"The reason for requiring an act is, that an act implies a choice, and that it is felt to be impolitic and unjust to make a man answerable for harm, unless he might have chosen otherwise." Holmes, COMMON LAW 54 (1881).

"For legal purposes it is enough to say that no involuntary action, whatever its effects may produce, amounts to a crime by the law of England." 2 STEPHEN, History of the Criminal Law of ENGLAND 100 (1883).

193. "Acts, then, in the eye of the law are such muscular motions as are preceded by the peculiar phenomenon entitled will." AMOS, THE ScIENCE of LAw 101 (1874).

"External acts are such motions of the body as are consequent upon determinations of the will." 1 AUSTIN, JURISPRUDENCE 376 (1879).

"An act or action is a name given to an event in so far as it comes to be considered as having had the human will for the immediate cause of it." 1 BENTHAM, JUDICIAL EVIDENCE 48 (1827).

"That is a man's act which he wills to do, exercising a choice between acting and forbearing, and the strongest moral compulsion still leaves freedom of such choice." Clerk \& LINDSEII, Torts 7 (2d ed. 1896).

"Acts are movements of the will." Holland, JuRISprudence 72 (1880).

"Without the function of the will, there can be no physical action." Stone, C.J. in Parsons v. State, 81 Ala. 577, 610 (1886).

"An act is always a voluntary muscular contraction and nothing else." HoLMEs, Common Law 91 (1881).

"An act is the bodily movement which follows immediately upon a volition." MarkBy, Elements of LAW \& 215 (4th ed. 1889).

"We mean by it [act] any event which is subject to the control of the human will." SALMOND, JuRisprudence 381 (7th ed. 1924).

194. "Will is as necessary an element of intent as are reason and judgment." Simmons, C.J. in Flanagan v. State, 103 Ga. 619, 626, 30 S.E. 550, 552 (1898).

"Accountability for crime, pre-supposes a criminal intent and that requires a power of reasoning upon the character and consequences of the act; a will subject to control. For this reason it is, that a homicide, committed under the influence of uncontrollable passion is not murder." Nisbet, J. in Roberts v. State, 3 Ga. 310, 328 (1847).

See also Turner, Mental Element in Crimes at Common Law in THE MODERN ApProach to Criminal LAW 195, 203 (Radzinowicz and Turner ed. 1945).

Lack of volition due to an external force is well recognized as a defense. Note the following:

"If there be an actual forcing of a man, as if $A$ by force take the arm of $B$ and the weapon in his hand, and therewith stabs $C$, whereof he dies, this is murder in A, but B is not guilty." 1 HALE, P.C. 434 (1736).

"A man may throw himself into a river under such circumstances as render it not a voluntary act; by reason of force, applied either to the body or the mind." Erskine, J. to jury in Reg. v. Pitts, C. \& M. 284, 285 (1842). Cited with approval in Patterson v. State, 181 Ga. 698, 705, 184 S.E. 309, 313 (1936); Whaley v. State, 157 Fla. 593, 595, 26 So.2d 656, 658 (1946); State v. Myers, 7 N.J. 465, 475, 81 A.2d 710, 715 (1951). See discussion of State v. Myers in Knowlton, Criminal Laze and Procedure, 6 Rutgers L. REv. 112, 117-120 (1951). 
necessarily negatives volition, it follows logically that irresistible impulse should constitute a defense. This being so, it becomes important to consider what reasons have been given by judges and writers who take a contrary view.

The principal reasons advanced for not recognizing irresistible impulse, even though the product of mental disease, are the following: 1. An impulse to do harm by one who knows the difference between right and wrong can not be irresistible. ${ }^{195}$ 2. Difficulty of proof. ${ }^{190}$ 3. Impracticality of application. ${ }^{197}$ 4. Danger to society, since re-

195. "The possibility of the existence of such a mental condition is too doubtful." Chalmers, J. in Cunningham v. State, 56 Miss. 269, 279 (1879).

"For myself I can not see how a person who rationally comprehends the nature and quality of an act, and knows that it is wrong and criminal, can act through irresistible innocent impulse." Brannon, J. in State v. Harrison, 36 W. Va. 729, 751, 15 S.E. 982, 980 (1892). Quoted with approval by Skeel, J. in State v. Cumberworth, 69 Ohio App. 239, 247, 43 N.E.2d 510, 513 (1942) and by Jeffers, J. in State v. Maish, 29 Wash.2d 52, 60, 185 P.2d 486, 490 (1947).

"That the person pretends he is impelled by an irresistible and overwhelming impulse to commit the act will not make a defense." Westbrook, J. to jury in People v. Waltz, 50 How. Pr. 204, 214 (N.Y. 1874).

"Such irresistible impulse to commit an act which he knows is wrong or unlawful (if it ever exists) does not constitute the insanity which is a legal defense." McKinstry, J. in People v. Hoin, 62 Cal. 120, 121 (1882).

"But if an influence be so powerful as to be termed irresistible, so much the more reason is there why we should not withdraw any of the safeguards tending to counteract it. There are three powerful restraints existing, all tending to the assistance of the person who is suffering under such influence-the restraint of religion, the restraint of conscience, and the restraint of law. But if the influence itself be held a legal excuse, rendering the crime dispunishable, you at once withdraw a most powerful restraint-that forbidding and punishing its perpetration." Bramwell, B. in Reg. v. Haynes, 1 F. \& F. 666, 667 (1859).

"We do not know that the impulse was irresistible, but only that it was not resisted. Whether irresistible or not must depend upon the relative force of the impulse and the restraining force, and it has been well said that to grant immunity from punishment to one who retains sufficient intelligence to understand the consequences to him of a violation of the law, may be to make an impulse irresistible, which before was not." Temple, J. in People v. Hubert, 119 Cal. 216, 223, 51 Pac. 329, 331 (1897).

The same idea was cynically expressed by a Canadian judge as follows: "If you can not resist an impulse in any other way, we will hang a rope in front of your eyes, and perhaps that will help." Riddell, J. in The King v. Creighton, 14 Can. Cr. Cas. 349, 350 (1908).

196. "It seems to us, however, that in the view suggested the difficulty would be great, if not insuperable, of establishing by satisfactory proof whether an impulse was or was not 'uncontrollable." " McGowan, J. in State v. Bundy, 24 S.C. 439, 445 (1886). To the same effect see Davis, J., in People v. Coleman, 1 N.Y. Crim. R. 1, 3 (1881) and McIver, J. in State v. Levelle, 34 S.C. 120, 131, 13 S.E. 319, 321 (1890).

"In truth, there are no means by which to judicially determine whether a criminal impulse, which has been yielded to, is uncontrollable or not, unless by accepting the statement of the criminal upon that subject." Note, Insanity as a Defense-Irresistible Imprilse, 63 AM. ST. REP. 79, 100 (1898).

To the same effect see OpPEnhenMER, The CRIMINal ResponsibItITy of Luna-

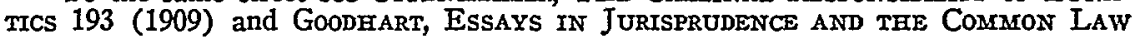
47 (1931).

197. The possibility of the existence of such a mental condition is . . . too incapable of a practical solution to afford a safe basis of legal adjudication." Chalmers, J. in Cunningham v. State, 56 Miss. 269, 279 (1879). 
fusal to recognize defense of irresistible impulse will act as a deterrent to the commission of crime. ${ }^{198} 5$. There is no need for allowing the defense, since after conviction clemency can be accorded persons who as a result of mental disease were irresistibly impelled to commit the harm in question. ${ }^{199}$

When a judge states that a person who knows right from wrong can not be irresistibly impelled to do wrong, he is departing from his judicial function and is assuming the role of an expert medical witness, ${ }^{200}$ for which he is in no way qualified. That an impulse, re-

"While the court fully appreciates the force of the reasoning of the courts accepting the doctrine of irresistible impulse and the logic of the position from the standpoint of the psychiatrist, nevertheless there are many grave objections to this doctrine in its practical application ..."Green, C.J. in Davis v. State, 161 Tenn. 23, 33, 28 S.W.2d 993, 996 (1930).

"The vagueness and uncertainty of the inquiry which would be opened and the manifest danger of introducing the limitation claimed into the rule of responsibility in cases of crime, may well cause courts to pause before assenting to it." Andrews, J. in Flanagan v. People, 52 N.Y. 467, 470 (1873).

198. "The medical man called for the defence defined homicidal mania to be a propensity to kill, and described moral insanity as a state of mind, under which a man, perfectly aware that it was wrong to do so, killed another under an uncontrollable impulse. This would appear to be a most dangerous doctrine, and fatal to the interests of society and security of life." Wightman, J. to jury in Reg. v. Burton, 3 F. \& F. 772,780 (1863).

"If juries were to allow it as a general motive, operating in cases of this character, its recognition would destroy social order, as well as personal safety." Stone, J. in Boswell v. State, 63 Ala. 307, 321 (1879).

"Indeed it would seem dangerous to society to say that a man who knows what is right and wrong may nevertheless, for any reason, do what he knows to be wrong without any legal responsibility therefor." Valentine, J. in State $\nabla$. Nixon, 32 Kan. 205, 212, 4 Pac. 159, 163 (1884). To same effect see Andrews $J$. in Flanagan v. People, 52 N.Y. 467, 470 (1873) ; Sherwood, J. in State v. Pagels, 92 Mo. 300, 317, 4 S.W. 931, 937 (1887).

"It is the fantastic theory of uncontrollable impulse which, if it were to become part of our criminal law, would be merely subversive." Hewart, L.C.J. in Appeal of Kopsch, 19 Cr. App. R. 50, 51 (1925).

199. "There are doubtless some cases, like that of Hadfield's Case, 27 How. St. Tr. 1281, in which the fear of punishment does not restrain, but where the rule works manifest injustice the unfortunate defendant is in some way saved from punishment." Temple, J. in People v. Hubert, 119 Cal. 216, 224, 51 Pac. 329, 331 (1897).

"Let your Lordships dismiss from your minds the fear that anybody who has acted under an uncontrollable impulse which he can not resist when he commits the crime, is likely to be hanged. In the Home Office every case is considered, the report of the Judge after conviction has taken place in a case of this kind is studied, and in such a case the extreme penalty would never be inflicted." Lord Chancellor Haldane in debate on Lord Darling's bill. 57 H.L. DEB. 472 (5th ser. 1924).

"Where there is a compelling impulse of that kind it is always taken into account either by the Judge at the trial or, in the event of conviction, by the Secretary of State when he comes to consider the sentence." Viscount Cave in debate on Lord Darling's bill. 57 H.L. DEB. 476 (5th ser. 1924). To same effect see Lord Sumner, 57 H.L. DEB. 458; (5th ser. 1924) and Lord Chief Justice Hewart, 57 H.L. DEB. 469 (5th ser. 1934).

200. The Supreme Court of the United States reversed a conviction because the trial judge expressed a medical opinion for which there was no evidence. Quercia v. U.S. 289 U.S. 466 (1933).

"It was, for a long time, supposed that men, however insane, if they knew an act to be wrong, could refrain from doing it. But whether that supposition is cor- 
sulting from mental disease, may be irresistible is supported by a mass of medical opinion. ${ }^{201}$ As on many medical questions there is a contrary opinion, but it is advanced by relatively few members of the profession. ${ }^{202}$

Dr. Philip Q. Roche of Philadelphia, Chairman of the Committee on Forensic Psychiatry of the Group for the Advancement of Psychiatry, recently put to the members of this Group the following question: "Are there cases where a person, suffering from mental derangement, knows that it is wrong to inflict bodily harm (killing, maiming, ravishing) upon another person, but owing to the mental derangement is incapable of controlling (resisting) the impulse to commit such bodily harm?" One hundred and two answers were received, of which ninety-three were "yes" and nine were "no." 203 Six members of the Group expressed the opinion that no definite answer to the question could be given.

rect or not, is a pure question of fact. The supposition is a supposition of fact,in other words, a medical supposition,-in other words, a medical theory. Whether it originated in the medical or any other profession, or in the general notions of mankind, is immaterial. It is as medical in its nature, as the opposite theory." Doe J. in State v. Pike, 49 N.H. 399, 437 (1870).

201. KIrChoff, Handbook of INSANITy 93 (1893); 1 Clevenger, Medical JuRISprudence of Insanity 172 (1898); Lewis, A Text-Book of Mental Disease 207 (1899) ; Maudsley, Responsibility in Mental Disease 143 (Äm. ed. 1899); Berkeley, Mental Disease 120 (1900) ; Brower-Bannister, Practical Manual of Insanity 396 (1902); Defendorf, Clinical Psychiatry 389 (1902); Cratg, Psychological Medicine 71 (2d ed. 1912) ; Clouston, Mental Diseases 338 (6th ed. 1904) ; Bruce, Studies in Clinical Psychiatry 27 (1906) ; Bianchi, TextBook of Psychiatry 633, 634 (1906) ; Jacoby, The Unsound Mind and the LAw 13 (1918) ; Goodwin, The Lunatic and the Law 255 (1924); Singer and KroHn, INSANITY AND LAW 161, 212 (1924) ; STODdaRT, Mind AND ITs Disorders 257, 258 (5th ed. 1926); EAst, Forensic PsychIATRY 358 (1927); Overholser, The Role of Psychiatry in the Administration of Criminal Justice, $93 \mathrm{~J}$. AM. MED. Ass'N 830 (1929) ; White, Outlines of Psychiatry 98 (12th ed. 1929) ; Sadler, Theory aNd Practice of Psychiatry 172 (1936); Tredgold, Mental Deficiency 346 (6th ed. 1937); Noyes, Modern Climical Psychiatry 88 (3d ed. 1948). See also 3 Witthaus and Becker, Medical Jurisprudence 247 (2d ed. 1909).

"The English writers use the term insanity with irresistible impulse, the French speak of obsessions with irresistible tendencies, while the Germans have largely employed the expression 'Zwangneurose,' compulsion neurosis." Dercum, A ClinICAL Manual of Mental Diseases 190 (2d ed. 1917).

202. See Zinboorg, Mind, Medicine and Man 274 (1943); Hamblin Sirite, Psychology of tHe Crminas 179 (2d ed. 1933); Henderson, Psychiatry and the Criminal Law, 4 Psychiat. Q. 114 (1930); cited by Hal,, Principles of the Crmininal Law 515, 507, 518 (1947).

Irresistible impulses are rare. Singer aNd KroHn, INSANITY AND LAW 161 (1924) ; Rosanoff, Manual of Psychiatry 322 (1920); Gordon, Morbid Impulses, 12 J. Crim. L. ANd Criminology 604 (1922) ; Meagher, Crime and Iiwsanity, 14 J. CRIM. L. AND CRIMINologY 46, 55 (1923) cited by Waite, Irresistible Impulse and Criminal Liability 23 MICH. L. Rev. 443, 455 (1925). To the same effect see Whitman, Capital Punishment and Irresistible Impulse as a Defense, 5 Notre DaMe LAw. 188,195 n. (1930).

203. Professor Jerome Hall, who has made an extensive study of the relation of mental derangement to criminal responsibility, states that "The essential, specific consequence, in terms of the instant problem, is that diseased volition does not exist apart from diseased intelligence." Hall, General Principles of Criminal Law 
In connection with the opinion that an impulse resulting from medical disease may be irresistible, it is recognized that in such case the intellectual powers will also be affected, for the idea that a medical disease may affect but a single function of the mind has been long abandoned. ${ }^{204}$ However, this intellectual impairment may, and frequently does, fall short of an incapacity to distinguish between right and wrong.

The objection that irresistible impulse is difficult to prove is not an adequate reason for rejecting the defense. A similar objection may be made to other types of mental disease. This was clearly recognized by the Supreme Court of Utah in an opinion by Hansen, J. who stated that "Insanity in all its forms is frequently difficult to determine with certainty, and yet courts all recognize that, if an accused does not know right from wrong and does not know the nature and quality of the act charged he should not be punished."205

Some physical diseases are difficult to prove, ${ }^{206}$ yet it is not likely that a court would refuse to receive evidence, otherwise admissible, of the existence of any of these diseases merely because of the difficulty of proof.

524 (1947). He supports the theory of the "integration of the self" according to which, as he states, "any interaction with the environment is integrated in the sense that the various functions of the personality coalesce and act as a unit." Id. at 521. Professor Hall's view is discussed with approval in CleckLey, The MAsk of SANITY 500, 501 (2d ed. 1950).

With regard to the question propounded by $\mathrm{Dr}$. Roche, which has been set forth in the text, Professor Hall states "The point is that to really know that it is wrong to inflict a serious injury on another person implies a sensitivity and an emotional tone permeating the cognition." Letter to the writer dated March 8, 1952. With this qualification Professor Hall expresses the opinion "that there can be no irresistible impulse to inflict a serious harm by a person who really knows that it is wrong to do so." Ibid.

204. "The nature of impulsive conduct generally brings out the point that irresistible impulse can not be regarded as an isolated phenomenon apart from the emotional and cognitive processes of mind." GLUECK, MENTAL Disorder AND THE CrIminal Law 310 (1925).

"Although the 'irresistible impulse' doctrine has given rise to much criticism, it seems fairer and more in accordance with psychologic teaching to consider the individual as a unit with cognitive, conative and affective aspects, rather than as a 'thinking machine' governed entirely by ethical or legal considerations of 'right and wrong." " Overholser, The Role of Psychiatry in the Administration of Jiustice, 93 J. AM. MED. Ass's 830 (1929). Permission to include this quotation was granted by the author.

205. State v. Green, 78 Utah 580, 600, 6 P.2d 177, 185 (1931).

"Is it more easy to ascertain a man's abstract knowledge of right and wrong, lawful and unlawful, than the exact amount of self-restraint which he possesses?" GuY, Principles of Forensic Medicine 338 (1845).

"There is no greater intellectual difficulty in understanding and applying the irresistible impulse test than there is in applying the tests under the McNaghten Rules." Barnes, $A$ Century of the McNaghten Rules, 8 CAмв. L.J. 300, 312 (1944).

206. For example, multiple sclerosis, chronic gastritis, coronary disease and trachoma. 
The objection that irresistible impulse would be difficult of application was answered by Somerville, J. in Parsons v. State, when he stated the following:

"It is no satisfactory objection to say that the rule above announced by us is of difficult application. The rule in McNaghten's Case is equally obnoxious to a like criticism. The difficulty does not lie in the rule, but is inherent in the subject of insanity itself." 207

The contention that refusal to allow the defense is a crime deterrent is not supported by any factual proof. It may well be doubted whether the conviction of a person actuated by an insane impulse will deter others from the commission of crime, particularly if they are similarly afflicted. A realistic answer to the contention was given by an editor of the Iowa Law Review as follows: "There are no statistics to prove that the ratio of crime in a state applying the irresistible test is any greater than that of a state not using such a test." 208

The argument by a judge, who is opposed to allowing irresistible impulse as a defense at the trial, that after conviction effect may be given to such a condition by the executive authority as an act of clemency seems to indicate an evasion of judicial responsibility. ${ }^{200}$ If medical experts are prepared to testify that a person at the time the harm was committed was suffering from an irresistible impulse, the result of mental disease, this testimony, which is relevant to the issue of guilt, should be presented at the trial and not after conviction at an investigation conducted with a view to clemency.

It having been shown that irresistible impulse, resulting from mental derangement, is generally recognized by psychiatrists, and that according to a fundamental principle of the criminal law it should constitute a defense, the question then arises as to how the rule of criminal responsibility should be stated so as to include this defense. Should "irresistible impulse" simply be added as a test to the "right and wrong test," so that it would be stated there is no responsibility if, at the time of committing the harm in question, the defendant was suffering from mental derangement as a result of which he (1) was unable to dis-

207. 8 Ala. $577,593,8$ So. 854,864 (1887).

208. 32 Iowa L. REv. 714, 718 (1947). That the defense of irresistible impulse "constitutes a threat to the security of society does not stand up under the light of experience." Hoedemaker, "Irresistible Impulse" as a Defense in Criminal Laz, 23 WASH. L. REV. 1, 7 (1948).

209. See Weatherly, A Plea for the Insane 156 (1918); Carsweli, Trial of Ronald True 40 (1925); Henderson and Gillespie, Text-Book of Psychiatry 587 (4th ed. 1937). 
tinguish between right and wrong or (2) was irresistibly impelled to commit the harm? No; for a legal rule should not be stated in terms of the symptoms of mental disease. ${ }^{210}$ A great defect of the M'Naghten Rules is that they crystallized existing theories of mental disease. ${ }^{211}$ A rule of law should be based on a legal principle, and psychiatric testimony like other evidence should be considered to the extent that it is relevant to the rule. A test, based upon a sound legal principle and capable of being applied to all types of mental disease, was recommended in 1913 by a committee of lawyers and physicians. ${ }^{212}$ The recommended test is as follows: "No person suffering from mental disease shall hereafter be convicted of any criminal charge, when at the time of the act or omission alleged against him, he did not have, by reason of such mental disease, the particular state of mind that must accompany such act or omission in order to constitute the crime charged." 213

210. "Thence has arisen so many ridiculous and untenable opinions, unsound and illogical propositions, unsafe and dangerous precedents. A regards motive as sufficient test; $B$ requires knowledge of morality or immorality of act; $C$ demands a comprehension of its relations to the law; $D$ argues from the presence or absence of selfrestraint; $E$ considers the existence of delusion essential ; $F$ associates delusion with act; $G$ rejects the mental unless corroborated by the physical condition; $H$ commingles insanity with crime; and ALL contribute somewhat to involve the question in almost inextricable perplexity. We might extend this list: to do so would be merely to repeat what we have already propounded." WILLIAMS, UNSOUNDNESS OF MIND 205 (1856).

211. "The knowledge test in all its forms, and the delusion test, are medical theories introduced in immature stages of science in the dim light of earlier times, and subsequently, upon more extensive observations and more critical examinations, repudiated by the medical profession." Doe, J. in State v. Pike, 49 N.H. 399, 437 (1870). See Keedy, A Problem of First Degree Murder: Fisher v. United States, 99 U. of PA. L. REv. 267, 290 (1950).

212. Committee on Insanity and Criminal Responsibility of the American Institute of Criminal Law and Criminology.

The members of the Committee were as follows:

Albert C. Barnes, Judge of the Superior Court, Chicago.

Archibald Church, Professor of Mental Diseases and Medical Jurisprudence, Northwestern University.

Walter Wheeler Cook, Professor of Law, University of Chicago.

William S. Forrest, Lawyer, Chicago.

Adolf Meyer, Professor of Psychiatry, Johns Hopkins University.

William E. Mikell, Professor of Law, University of Pennsylvania.

Harold N. Moyer, Physician, Chicago.

Morton Prince, Professor of Nervous Diseases, Tufts College Medical School.

William A. White, Superintendent, Government Hospital for the Insane, Washington, D. C.

Edwin R. Keedy, Chairman, Professor of Iaw, Northwestern University.

213. 3 J. CRim. L. and Criminology 719, 720 (1913).

The Medico-Legal Bar Association Committee of the Pennsylvania Psychiatric Society approved the proposed bill on March 2, 1952 and stated the following reasons for such approval: "(1) That mental disorder not be regarded as a constant quantity, (2) that the Bill embodies no medical or psychological theories, (3) that the Bill does not limit the defense to any form or symptoms of mental disease, (4) that it eliminates any legal definition of insanity, does not employ the word 'insanity', nor attempt to state what constitues mental disease, (5) that the Bill clearly separates the legal and medical functions of the trial, (6) that the Bill limits the testimony of the medical 
Under this test, if there was evidence of irresistible impulse, the trial judge would instruct the jury as follows:

"A mental requirement of every crime is volition, which means that a person is able to exercise a choice either to act or not to act. In this case there was medical testimony that the defendant was suffering from mental disease and as a consequence was irresistibly impelled to commit the harm with which he was charged. If you find from such testimony that the defendant was so impelled, then the necessary volition was lacking and the defendant should be acquitted."

Criminal responsibility is a legal question and the rules for determining such responsibility should be based on legal principles. Mental disease, on the other hand, is a medical problem and when set up as a defense to a criminal charge should be established by the testimony of qualified physicians. It is then the function of the jury to apply the rule of law, as laid down by the trial judge, to the medical testimony and arrive at a verdict accordingly.

expert to the opinion regarding the mental condition of the defendant at the time of the alleged offense; that the judge have the task of describing to the jury the mental element required in the crime charged, and finally (7) that the bill provides that the function of the jury be to determine whether the defendant, as a result of the mental condition determined by the medical expert, has a particular state of mind as delineated by the judge." 